\title{
REVISÃO DA LITOESTRATIGRAFIA DA FAIXA SÃO ROQUE/SERRA DO ITABERABA (SP)
}

\author{
Caetano JULIANI \\ Paulo BELJAVSKIS
}

\section{RESUMO}

O grande número de publicações existentes sobre a geologia da Faixa São Roque/Serra do Itaberaba, que propõem ou se utilizam de diversas denominações litoestratigráficas, dificulta muitas vezes o entendimento da sua evolução geológica e de sua litoestratigrafia.

Este trabalho visa à organização da nomenclatura e das propostas litoestratigráficas da Faixa e, para tanto, a maioria das publicações sobre o assunto foi revisada, incluindo os artigos onde as primeiras denominações litoestratigráficas foram efetuadas.

Através de uma análise crítica comparativa da bibliografia e, baseando-se no mapeamento em 1:25.000 efetuado na região das serras do Itaberaba e da Pedra Branca, é aqui proposta a separação das supracrustais da Faixa em duas unidades litoestratigráficas maiores, quais sejam: o Grupo Serra do Itaberaba e o Grupo São Roque.

O Grupo Serra do Itaberaba é constituído pelas formações Morro da Pedra Preta, vulcano sedimentar e basal; Nhanguçu, superior e composta essencialmente por metapelitos com andaluzita ou manganesíferos com lentes subordinadas de rochas carbonáticas e calciossilicáticas; e Pirucaia, predominantemente quartzítica, que deve corresponder a litofáceis depositadas nas margens da bacia sedimentar, podendo ser cronocorrelatada a ambas formações já citadas, mais especialmente à Formação Nhanguçu.

No Grupo São Roque podem ser reconhecidas as formações Piragibu, metapelítica, com poucas lentes de metaconglomerados e de metavulcânicas na sua base, Pirapora do Bom Jesus, essencialmente vulcânica/vulcanoclástica e com biohermas e cálcio-filitos; Estrada dos Romeiros, com metapelitos e metarenitos rítmicos; e Boturuna, predominantemente metarenítica/arcoseana.

A Formação Piragibu é basal nas regiões das serras do Itaberaba e da Pedra Branca e do Morro Doce e, no Sinclinório de Pirapora do Bom Jesus, a formação homônima é basal e seguida pela Formação Estrada dos Romeiros, que deve corresponder a fácies mais distais da Formação Piragibu, capeada pela Formação Boturuna.

\section{ABSTRACT}

A great number of publications on the geology of the São Roque/Serra do Itaberaba Belt (São Paulo State, Brazil) introduce and use diverse lithostratigraphic denominations, creating difficulties to a clear understanding of the geological evolution and lithostratigraphy of the metamorphic belt.

This paper seeks an organization of the various nomenclatures and litostratigraphic suggestions for the Belt. A review of the essential publications about the subject is made, including those where the first litostratigraphic denominations were cited.

After a comparative and critical analysis of the bibliography and, taking as a basis the geologic map 1:25.000 of the Itaberaba and Pedra Branca mountains, a separation of the supracrustal rocks which constitute the Belt in two major litostratigraphic units is proposed: Serra do Itaberaba Group and São Roque Group.

The Serra do Itaberaba Group is subdivided into the Morro da Pedra Preta, Nhanguçu and Pirucaia formations. The Morro da Pedra Preta Formation is a volcano-sedimentary sequence, and is basal to the Nhanguçu, mainly composed by andalusite-bearing and manganesiferous metapelites, with some small lenses of carbonatic and calc-silicatic rocks. The Pirucaia Formation is predominantly quartizitic and probably represents the lithofacies deposited in the margins of the two other formations, particularly of the Nhanguçu Formation.

In the São Roque Group the following formations can be recognized: Piragibu, composed by metapelites with few lenses of metaconglomerates and metavolcanics; Pirapora do 
Bom Jesus, essentialy volcanic/volcaniclastic, with bioherms and calc-phyllites; Estrada dos Romeiros, with rhythmic metapelites and metarenites and, finally, the metarenitic arcosean Boturuna Formation.

The Piragibu Formation is basal in the area of the Itaberaba, Pedra Branca and Morro Doce Mountains. In the Pirapora Synclinorium, the homonymic formation is basal to the Estrada dos Romeiros Formation, which corresponds to the more distal facies of the Piragibu Formation, covered by the Boturuna Formation.

\section{INTRODUÇÃO}

A geologia pré-cambriana dos estados de São Paulo e do Paraná vem sendo estudada desde o Período Colonial, e ainda mais intensamente após a criação da Comissão Geográfica e Geológica da Província de São Paulo, em 1886. Grande parte destas pesquisas concentra-se nas supracrustais historicamente consideradas como Açungui e São Roque, resultando em inúmeras publicações e enorme acúmulo de dados, raramente tratados de modo integrado e sistemático.

Apesar da quantidade e profundidade destes estudos, ainda permanecem controvérsias a respeito das subdivisões litoestratigráficas, correlações geológicas, eventos deformacionais, tipos de metamorfismo, etc.

Este trabalho, que visa analisar a litoestratigrafia das unidades São Roque e Serra do Itaberaba e as possíveis correlações entre as formações definidas, resulta de ampla revisão bibliográfica e de estudos geológicos em campo, petrológicos, estruturais e petrogenéti$\cos$, efetuados na região nordeste da cidade de São Paulo (JULIANI et al., 1986 e JULIANI, 1993). Tem também como objetivo o estabelecimento de algumas correlações preliminares com as unidades geológicas mais próximas, situadas além das zonas de cisalhamento de ItuJundiuvira, Taxaquara e Rio Jaguari.

\section{SÍNTESE GEOLÓGICA REGIONAL}

As rochas supracrustais que compõem os grupos São Roque e Serra do Itaberaba afloram continuamente em uma faixa com pouco mais de $180 \mathrm{~km}$ de comprimento e $50 \mathrm{~km}$ de largura máxima, que se acunha no sentido nordeste nas proximidades de Monteiro Lobato (FIGURA 1). Ocorrem ainda nas proximidades de Araçoiaba da Serra, ao redor da intrusão alcalina de Ipanema (BISTRICHI et al., 1981).

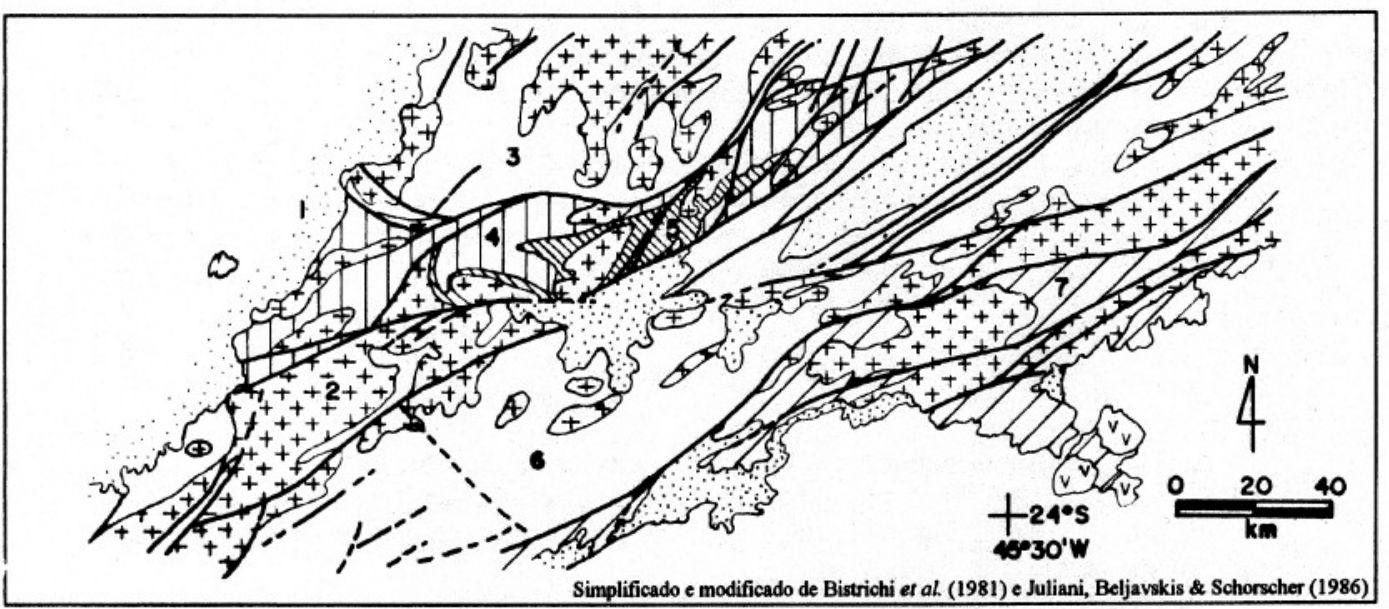

FIGURA 1 - Esboço geológico regional onde: (1) Coberturas sedimentares paleozóicas e cenozóicas; (2) Rochas granitóides diversas; (3) Grupos Amparo, Paraíba do Sul e Itapira; (4) Grupo São Roque, incluindo terrenos gnáissico-migmatíticos a nordeste de posicionamento indefinido; (5) Grupo Serra do Itaberaba; (6) Complexo Embu (Paraíba); (7) Complexo Costeiro.

A delimitação da faixa com as demais unidades geológicas da região se dá, segundo os mapas geológicos existentes, através das zonas de cisalhamento de Itu-Jundiuvira a norte, de Taxaquara e do Rio Jaguari a sul, e de Monteiro Lobato a leste. Parte das supracrustais que ocorrem além das zonas de cisalhamento que delimitam a Faixa, especialmente os metassedimentos e vulcânicas dos complexos Itapira, Igaratá e Embu são, no entanto, considerados como correlacionáveis aos grupos Serra do Itaberaba e São Roque, conforme CAVALCANTE \& KAEFER (1974), OLIVEIRA et al. (1985), SIMÕES et al. (1986), BATISTA et al. (1987), HASUI et al. (1989), DANTAS (1990) e JULIANI $(1992,1993)$. Assim, estas unida- 
des podem estender-se além das zonas de cisalhamento que tradicionalmente são consideradas seus limites.

O Grupo São Roque, como redefinido por JULIANI et al. (1986), é constituído predominantemente por filitos róseos, alaranjados, castanhos ou avermelhados, quando alterados, e cinza-esverdeados claros a escuros quando frescos. Apresentam comumente estruturas bandadas ou laminadas, dadas pela alternância de leitos mais ou menos quartzosos ou micáceos, muito freqüentemente com estruturas primárias preservadas, como estratificações rítmica, gradacional e cruzada, seqüências de Bouma, marcas de ondas, estromatólitos, brechas etc. (BETTENCOURT \& WERNICK, 1976; BERGMANN, 1988 e 1991; HACKSPACHER et al., 1989; PIRES et al., 1990). Subordinadamente ocorrem metaconglomerados, metarcóseos, metagrauvacas, quartzitos, cálcio-xistos, calcários metamórficos e metabasitos, geralmente formando lentes de dimensões variadas. O conjunto dos litotipos foi metamorfisado na fácies xisto verde de baixa pressão (tipo Abukuma ou New Hampshire), localmente alcançando grau metamórfico mais elevado devido à intrusão de corpos graníticos.

O Grupo Serra do Itaberaba distingue-se do anterior pela grande variedade de metamorfitos, destacando-se volumetricamente aqueles originados por atividades vulcânicas e vulcanoclásticas. E formado por metapelitos e rochas metabásicas (com metaintermediárias e metavulcanoclásticas associadas), além de metapsamitos (quartzitos puros e arcoseanos), metassedimentos manganesíferos, formações ferríferas, rochas calciossilicáticas e carbonáticas, estas de ocorrência relativamente restrita. Os litotipos encontram-se metamorfisados predominantemente na fácies anfibolito média, com variações para as fácies xisto verde superior ou anfibolito alto. Algumas lentes de rochas gnáissicas associadas às supracrustais representam antigos corpos graníticos deformados e outras, constituídas por granodioritos e tonalitos miloníticos, podem ser restos do embasamento siálico da seqüência.

Os litotipos do Grupo Serra do Itaberaba foram deformados complexamente, podendo ser reconhecidos padrões de dobramentos superpostos, com foliações plano-axiais associadas, que podem ser assim caracterizadas:

A S $_{1}$ é nas unidades basais uma xistosidade média a grossa encontrada nas rochas mais deformadas como relíquias ou em micrólitons contidos na $\mathrm{S}_{2}$, ou como $\mathrm{S}_{\mathrm{i}}$ em porfiroblastos de granada, cordierita e estaurolita. Em rochas menos deformadas é uma típica xistosidade subparalela ao acamamento e, nas unidades de topo, grada para uma xistosidade fina, para uma foliação filítica ou para uma clivagem ardosiana. A $S_{2}$ também é caracterizada como uma xistosidade, semelhante à $S_{1}$, mas tem os minerais metamórficos associados geralmente de granulação relativamente mais fina. Também apresenta gradações para xistosidade fina a foliação filítica nas unidades superiores do Grupo. Seguem-se a esta xistosidade eventos de crenulação, sendo a $S_{3}$ predominantemente uma crenulação discreta bem desenvolvida e com planos cerradamente espaçados, e a $\mathrm{S}_{4}$ uma crenulação zonal de intensidade bastante variável, além de outras crenulações locais.

Nos litotipos do Grupo São Roque a $S_{1}$ é representada por uma foliação filítica finamente espaçada, chegando a tornar-se uma clivagem ardosiana, muito semelhante à $S_{2}$ das unidades superiores do Grupo Serra do Itaberaba. Seguese uma clivagem de crenulação zonal a discreta $\left(\mathrm{S}_{2}\right)$, localmente contínua ou com aspecto de clivagem ardosiana. Em poucos locais da região da Serra do Itaberaba pode ainda ser observada uma tênue crenulação sobreposta à $\mathrm{S}_{2}$.

A presença de cianita apenas na $S_{1}$ dos metapelitos do Grupo Serra do Itaberada indica que o primeiro evento metamórfico deu-se sob pressão relativamente elevada (tipo Barrowiano - $\mathrm{P}_{\text {máx. }}$ entre 5 e $6 \mathrm{~kb}$ e $\mathrm{T}^{\circ}$ máx. entre 600 e $620^{\circ} \mathrm{C}$ ). Durante o desenvolvimento da $S_{2}$ a pressão máxima foi inferior a $5 \mathrm{~kb}$ (tipo Abukuma ou New Hampshire), pois não houve cristalização de cianita, e as temperaturas, mesmo alcançando a fácies anfibolito, foram mais baixas que no primeiro evento. A trajetória deste segundo evento metamórfico no campo P-T-t alinha-se com a definida pelo metamorfismo associado à $S_{1}$ do Grupo São Roque, da fácies xisto verde, sugerindo tratarse de um mesmo evento tectonometamórfico. As deformações associadas às dobras $\mathrm{D}_{2}$ do Grupo Serra do Itaberada foram também mais intensas que as associadas às $\mathrm{D}_{1}$ do Grupo São Roque, ambas vinculadas ao mesmo evento deformacional.

As idades dos grupos ainda não estão bem estabelecidas. Alguns autores consideram o Grupo Serra do Itaberaba como sendo do Proterozóico Médio a Inferior, com o Grupo São Roque sendo do Brasiliano (JULIANI et al., 1986), e outros como sendo um único Grupo, com a sedimentação iniciada a pouco mais de $1,8 \mathrm{Ga}$ e com os eventos de deformação, metamorfismo e granitogênese tendo ocorrido no Proterozóico Médio e Superior (TASSINARI et al., 1988; SADOWSKI \& TASSINA- 
RI, 1988; BERGMANN, 1988; DANTAS, 1990; HACKSPACHER et al. , 1992a,b).

As rochas granitóides ocupam grandes áreas da faixa pré-cambriana aqui abordada. São formadas por tipos diversos, geralmente porfiróides, de composição variando de granítica a granodiorítica, com características sin-, tardi- ou pós-tectônicos (HASUI et al., 1978; WERNICK \& GALEMBECK, 1986; JANASI \& ULBRICH, 1991).

\section{PROPOSTAS LITOESTRATIGRÁFICAS PARA A FAIXA SÃO ROQUE/SERRA DO ITABERABA}

Na FIGURA 2 são apresentadas as propostas de subdivisão estratigráfica da Faixa (incluindo suas posições cronoestratigráficas). Algumas delas incluem ainda informações sobre qual seria seu embasamento.

De modo geral serão destacados a seguir os trabalhos que introduziram as propostas litoestratigráficas, ou os que as modificaram. A revisão mais completa das bibliografias, incluindo os autores que adotaram as propostas preexistentes, pode ser encontrada no trabalho de JULIANI (1993).

A primeira subdivisão informal destes terrenos foi efetuada por DERBY (1878) no Estado do Paraná, quando denominou os terre- nos gnáissico-migmatíticos de série (metamorphica) crystallina, do Arqueano, e as rochas supracrustais de série (metamorphica) não crystallina, considerada como sendo do Siluriano Médio ou talvez do Cambriano.

OLIVEIRA (1888) chamou os terrenos atribuídos ao Arqueano de Primeira Série e os metassedimentos de Segunda Série, posicionada no Algonquiano. A Segunda Série foi posteriormente denominada de Série da Serra do São Francisco por OLIVEIRA (1889).

Muitos autores modernos consideram que a primeira denominação de São Roque seria devida a GONZAGA DE CAMPOS (1889) ao referir-se às camadas de São Roque com conotação litoestratigráfica. Entretanto, ao estudar os calcários da região de Sorocaba, o referido autor apenas julgou-os serem " ... a continuação das camadas de São Roque...”, não atribuindo à frase, portanto, sentido litoestratigráfico.

DERBY (1909) subdividiu as rochas metamórficas do Brasil em arqueanas, representadas pelos gnaisses e xistos, cambrianas, representadas pelos quartzitos, filitos etc. com mineralizações de ouro e ferro, e silurianas inferiores, onde incluiu os sedimentos pouco metamorfisados dos estados do Paraná e São Paulo.

Ao registrar pela primeira vez o nome de Série do Assunguy, OLIVEIRA (1916) a consi-

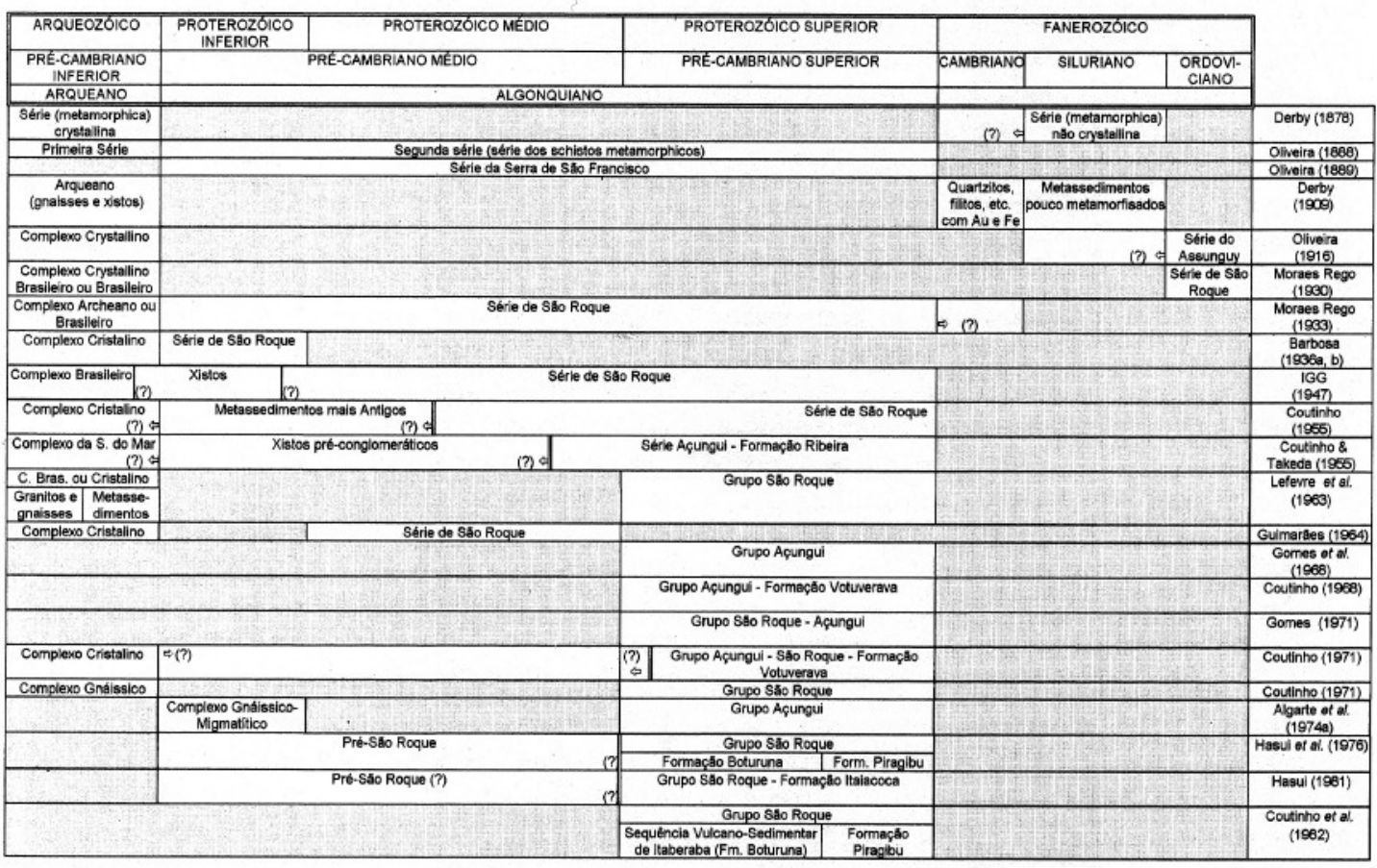

FIGURA 2 - Principais propostas litoestratigráficas da Faixa São Roque/Serra do Itaberaba. As linhas duplas correspondem a possíveis discordâncias erosivas. Referências complementares podem ser encontradas em JULIANI (1993), pág. 63. 
FIGURA 2 - Continuação

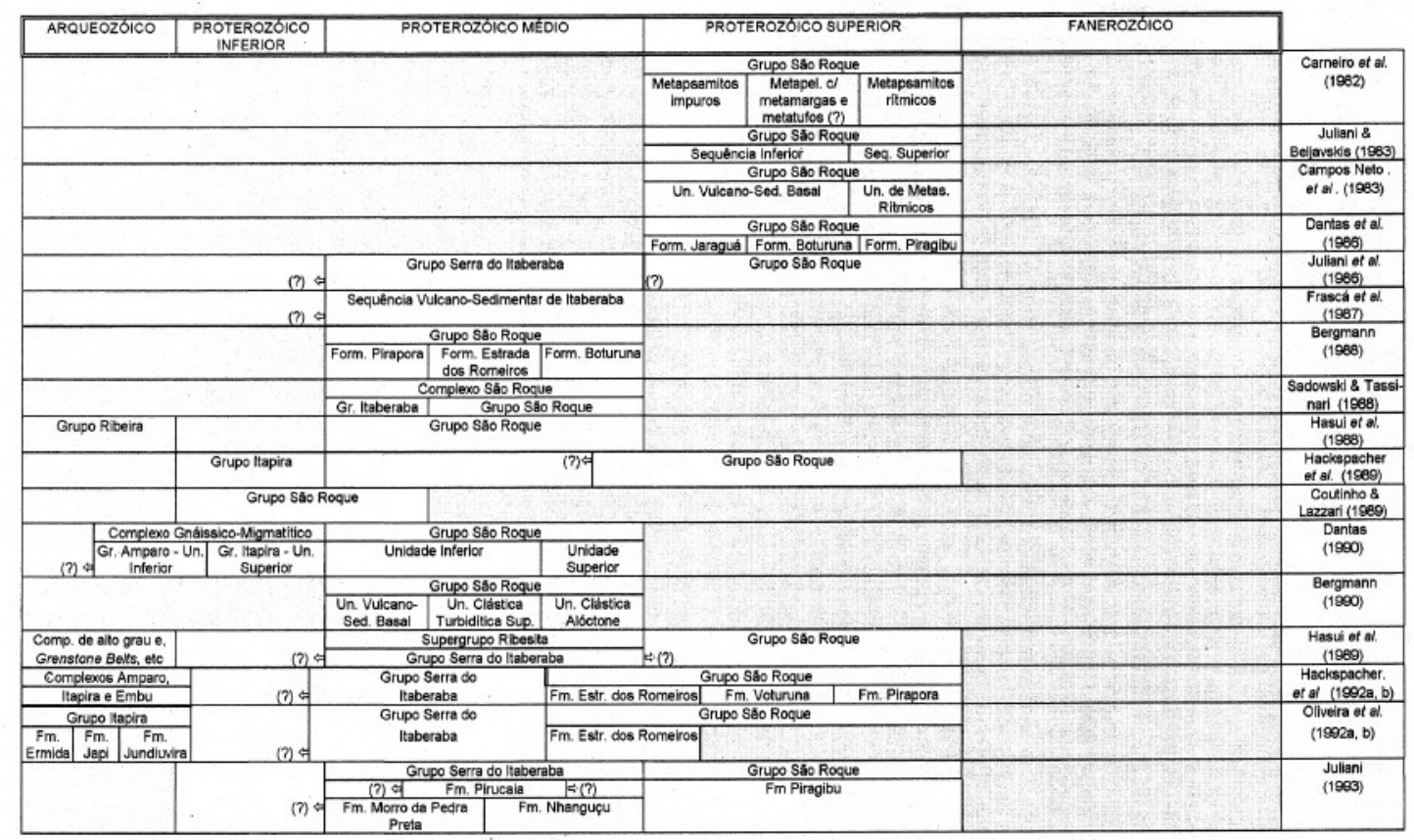

Referências bibliográficas complementares podem ser encontradas em Juliani (1993)

derou ordoviciana, mas sugeriu que poderia ser até siluriana. A Série estaria superposta ao Complexo Crystallino, do Arqueano, mais especificamente aos xistos do cristalino da Serra do Mar, e seria formada por xistos argilosos pouco metamorfisados, freqüentemente muito alterados pela ação intempérica, quartzitos e calcários.

BRANNER (1919) introduziu a denominação de Complexo Brasileiro para o Arqueano e posicionou a Série de Minas e correlatas (incluindo aí as supracrustais de São Paulo e do Paraná) no Paleozóico Inferior.

O primeiro registro do nome Série de São Roque foi feito por OLIVEIRA (1925) ao apresentar análises químicas de calcários de São Paulo e do Paraná, quando os distinguiu, quanto à proveniência, dos da Série de Assunguy.

MORAES REGO (1930) definiu a Série de São Roque como de idade ordoviciana e depositada sobre um embasamento arqueano, denominado de Complexo Crystallino Brasileiro ou Complexo Brasileiro. $\mathrm{O}$ autor afirmou ainda que a denominação Série de Assunguy havia sido introduzida por Eusébio Paula de Oliveira, ao descrever as formações metassedimentares do Estado do Paraná como análogas às da Série de São Roque, sendo então consideradas homólogas. O nome prioritário, segundo o autor, seria o da última série, que teria sido introduzido por Gonzaga de Campos em 1923 (GON-
ZAGA DE CAMPOS, 1925), o que não foi comprovado nesta revisão.

Neste período as denominações de Série de São Roque ou Série São Roque foram aceitas. pelos estudiosos, apesar de muitas vezes admitirem como prioritário o nome Açungui. Entretanto, vários dos pesquisadores ponderavam que a denominação Série de São Roque somente poderia ser mantida se não fosse constatada continuidade física entre os metassedimentos situados a norte-nordeste da Cidade de São Paulo e os do Vale do Ribeira.

Posteriormente as rochas supracrustais do Estado de São Paulo foram consideradas por MORAES REGO (1933) como algonquianas, com dúvidas se não seriam cambrianas, e posicionadas sobre o Complexo Archeano ou Complexo Brasileiro. Alguns autores modernos (CARNEIRO, 1983 e DANTAS, 1990, por exemplo) alegam que neste trabalho teria sido sugerida a subdivisão da Série de São Roque nas seqüências inferior e superior devido à afirmação do autor de que as rochas calcárias pareceriam dispor-se em um único horizonte estratigráfico, pois afloravam no topo de estruturas dobradas erodidas, o que não parece ser correto, pois Moraes Rego afirmou, na página 17: "...tendo em vista a complexidade de estructura, fica afastada actualmente qualquer tentativa de divisão da série em andares...".

BARBOSA (1936a, 1936b) adotou a denominação de Complexo Cristalino para o 
Arqueano e colocou a Série de São Roque no Proterozóico Inferior.

No trabalho do IGG (1947) a Série de São Roque (essencialmente algonquiana) foi colocada sobre uma unidade de xistos de limites cronológicos incertos, mas situada entre o Algonquiano Inferior e o Arqueano Superior, por sua vez colocada sobre o Complexo Brasileiro, ainda mais antigo. Este esboço litoestratigráfico tem sido confirmado em alguns dos estudos mais recentes, nos quais a unidade de xistos corresponde ao Grupo Serra do Itaberaba, inferior ao Grupo São Roque, como pode ser visto em JULIANI (1992), por exemplo.

A mesma dúvida em relação a estes xistos foi expressa por COUTINHO $(1955,1968 b)$, que os considerou como, possivelmente, mais antigos que os metassedimentos da Série de São Roque. Os xistos foram, desta forma, colocados no Algonquiano Médio-Inferior, mas foram também destacadas dúvidas se pertenceriam ou não ao Complexo Cristalino.

COUTINHO \& TAKEDA (1955) mantiveram a mesma concepção cronológica anterior, mas redenominaram as unidades como Complexo da Serra do Mar, Xistos pré-conglomeráticos (ou pré-Açungui) e Série Açungui ou Formação Ribeira.

LEFEVRE et al. (1963) introduziram a denominação de Grupo São Roque, do PréCambriano Superior, para as rochas supracrustais, e para o embasamento arqueano mantiveram o nome de Complexo Brasileiro ou Cristalino, subdividido numa unidade superior de metassedimentos e outra inferior, de granitos e gnaisses. A alteração do status da Série de Açungui para Grupo Açungui foi efetuada posteriormente por MARINI et al. (1967).

O termo de Série de São Roque foi mantido por GUIMARÃES (1964), ao elaborar uma síntese sobre a geologia do Brasil, mas a unidade foi colocada no Proterozóico Médio.

No período em que os estudos anteriormente citados estavam sendo efetuados, os pesquisadores que estudavam os metassedimentos associados às rochas gnáissico-migmatíticas das regiões de Embu-Guaçu, Mogi das Cruzes, da Serra do Japi e de Atibaia os consideravam, devido às semelhanças dos litotipos e mineralizações associadas, como pertencentes à Série de São Roque (MORAES, 1944a,b,c; KNECHT, 1950; VANDOROS \& FRANCO, 1966).

Até esta época a denominação São Roque foi mantida por ser desconhecida a presença de metassedimentos na região de Pilar do Sul, o que indicaria a continuidade física entre as uni- dades São Roque e Açungui. Caso fossem verificados estes metassedimentos naquela região considerava-se que todo o conjunto deveria ser denominado de Grupo Açungui, por ser este o nome consensualmente prioritário. Desta forma, a descoberta dos metassedimentos naquela região (HENNIES et al., 1967; HASUI et al., 1969; HASUI, 1973) conduziu a uma tendência de abandono do nome São Roque, mas alguns estudiosos preferiram denominar as unidades de São Roque-Açungui ou AçunguiSão Roque, como pode ser verificado na FIGURA 2 e nas citações feitas a seguir:

Cronologicamente colocados no PréCambriano Superior, os metassedimentos das proximidades de São Paulo foram denominados de Grupo Açungui por GOMES et al. (1968), Grupo Açungui-Formação Votuverava por COUTINHO (1968a), Grupo São RoqueAçungui por GOMES (1971), Grupo AçunguiSão Roque, Formação Votuverava, por COUTINHO (1971a), Grupo São Roque por COUTINHO (1971b) e Grupo Açungui, por ALGARTE et al. (1974), sendo que nestes dois últimos trabalhos foram atribuídos, respectivamente, os nomes Complexo Gnáissico (Arqueano) e Complexo Gnáissico-Migmatítico (Proterozóico Inferior) para o embasamento das supracrustais.

Após a descoberta, por HENNIES et al. (1967), da Falha de Taxaquara, HASUI et al. (1969) consideraram as rochas supracrustais situadas a norte da falha como pertencentes ao Grupo São Roque, distinto das supracrustais do Grupo Açungui, aflorante a sul da falha, por serem fisicamente descontínuos devido ao grande movimento transcorrente. A transcorrência teria, desta forma, justaposto diferentes bacias deposicionais que poderiam até ser cronocorrelatas.

Posteriormente HASUI (1973) verificou não ser possível a manutenção do nome Grupo São Roque para as supracrustais situadas a norte da falha e as considerou como parte do Grupo Açungui, apesar de ter reconhecido uma evolução deformacional distinta para ambas unidades e de estarem limitadas por grande zona de transcorrência.

A revisão dos problemas concernentes à evolução dos grupos São Roque e Açungui levou HASUI (1975 a,b) a retomar a denominação de Grupo São Roque, adotada de forma quase unânime nas publicações subseqüentes. Tal revisão baseou-se na premissa de que grandes blocos crustais ou conjuntos deles, limitados por grandes falhas, teriam evoluções geológicas distintas, justificando, portanto, conjuntos litoestratigráficos distintos. Este conceito arrai- 
gou-se na comunidade geológica, podendo ser bem exemplificado no Mapa Geológico do Estado de São Paulo de BISTRICHI et al. (1981).

A primeira tentativa de subdivisão do Grupo São Roque foi feita por HASUI et al. (1976) na região de Pirapora do Bom Jesus, onde foi distinguida a Formação Boturuna, Inferior (formada por metapelitos com lentes de quartzitos na base e rochas carbonáticas no topo), e a Formação Piragibu, Superior (filitos rítmicos com alternâncias de filito e quartzito de caráter flyschóide), conforme pode ser visto na FIGURA 3. Consideraram ainda que os metaconglomerados, três ocorrências de metavulcânicas e metassedimentos da fáceis anfibolito poderiam pertencer ao embasamento do Grupo, e que estas unidades poderiam também ser identificadas no Grupo Açungui (as colunas litoestratigráficas apresentadas para os dois grupos são, inclusive, muito semelhantes).

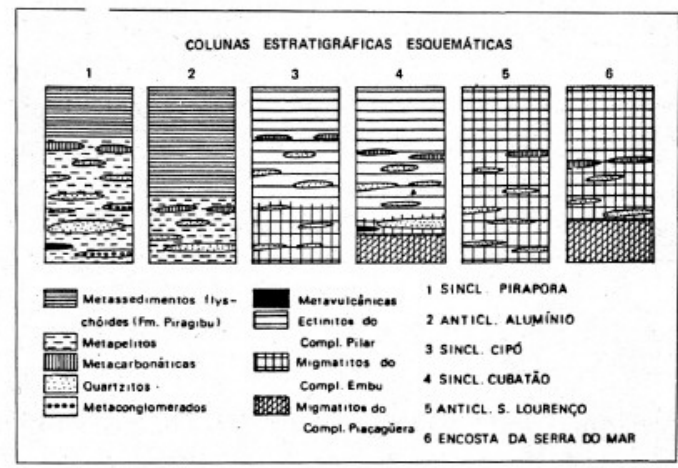

FIGURA 3 - Colunas litoestratigráficas dos grupos São Roque e Açungui, segundo HASUI et al. (1976), onde as unidades Metapelitos, Metacarbonáticas, Quartzitos, Metaconglomerados e Metavulcânicas correspondem à Formação Boturuna.

HASUI (1981) correlacionou o Grupo São Roque à Formação Itaiacoca do Grupo Açungui, tendo sugerido ainda a possibilidade de que os terrenos de mais alto grau metamórfico poderiam pertencer a uma unidade Pré-São Roque.

COUTINHO et al. (1982) consideraram que as rochas aflorantes na Serra do Itaberaba pertenceriam às unidades basais do Grupo São Roque, que no local seria subdivisível em uma seqüência vulcano-sedimentar inferior, com vulcânicas ou subvulcânicas básicas e seus tufos, bem como camadas argilosas, margas e sedimentos químicos, e uma superior, com sedimentos cabonáticos e ritmitos siltoargilosos, os quais poderiam corresponder a depósitos do tipo flysch. Estes conjuntos foram, respectivamente, correlacionados às Formações Boturuna e Piragibu de HASUI et al. (1976).
CARNEIRO et al. (1982) e CARNEIRO (1983) propuseram para a região compreendida entre o Pico do Jaraguá e a Serra dos Cristais a existência de unidades litoestratigráficas representadas por grandes pacotes de rochas denominados, da base para o topo, de metapsamitos impuros (metarcóseos, metarenitos, metagrauvacas, anfibolitos, metaconglomerados, quartzitos, calcários e rochas subvulcânicas riodacíticas), metapelitos, com uma subunidade intercalada de metamargas e prováveis metatufos (filitos laminados e grafitosos, quartzitos, micaxistos, xistos profiroblásticos, xistos com intercalações de metarenitos, rochas calciossilicáticas, anfibolitos, possíveis metatufos, anfibolitos bandados, calcários e dolomitos) e de metapsamitos rítmicos (metarenitos conglomeráticos, filitos laminados, metarcóseos, anfibolitos, metarenitos bandados), como pode ser observado na FIGURA 4.
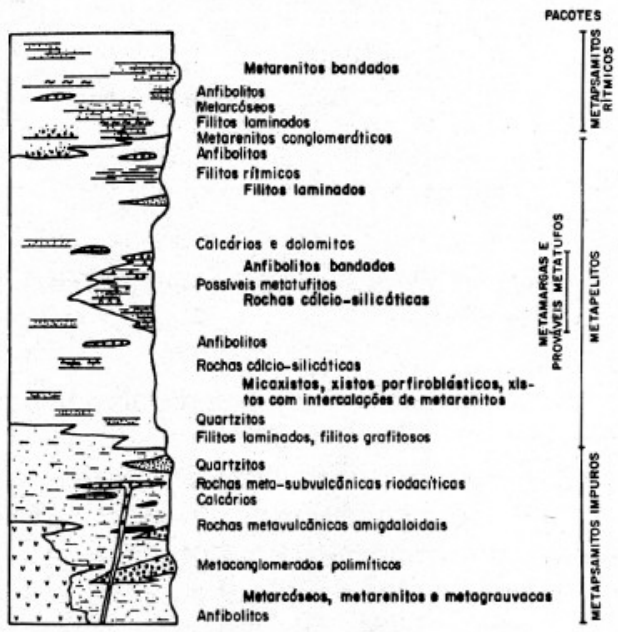

FIGURA 4 - Coluna litoestratigráfica proposta para a faixa entre o Pico do Jaraguá e a Serra dos Cristais por CARNEIRO (1983).

Na região da Serra do Itaberaba, JULIANI \& BELJAVSKIS (1983) propuseram a subdivisão do Grupo São Roque nas seqüências Superior (parcialmente correlacionável com a Formação Piragibu) e Inferior, vulcano-sedimentar (FIGURA 5), englobando essencialmente os mesmos conjuntos de litotipos descritos por COUTINHO et al. (1982). Sugeriram que a deposição teria ocorrido em uma bacia tafrogênica ensiálica, assim como a existência de possíveis discordâncias erosivas entre as duas unidades. 


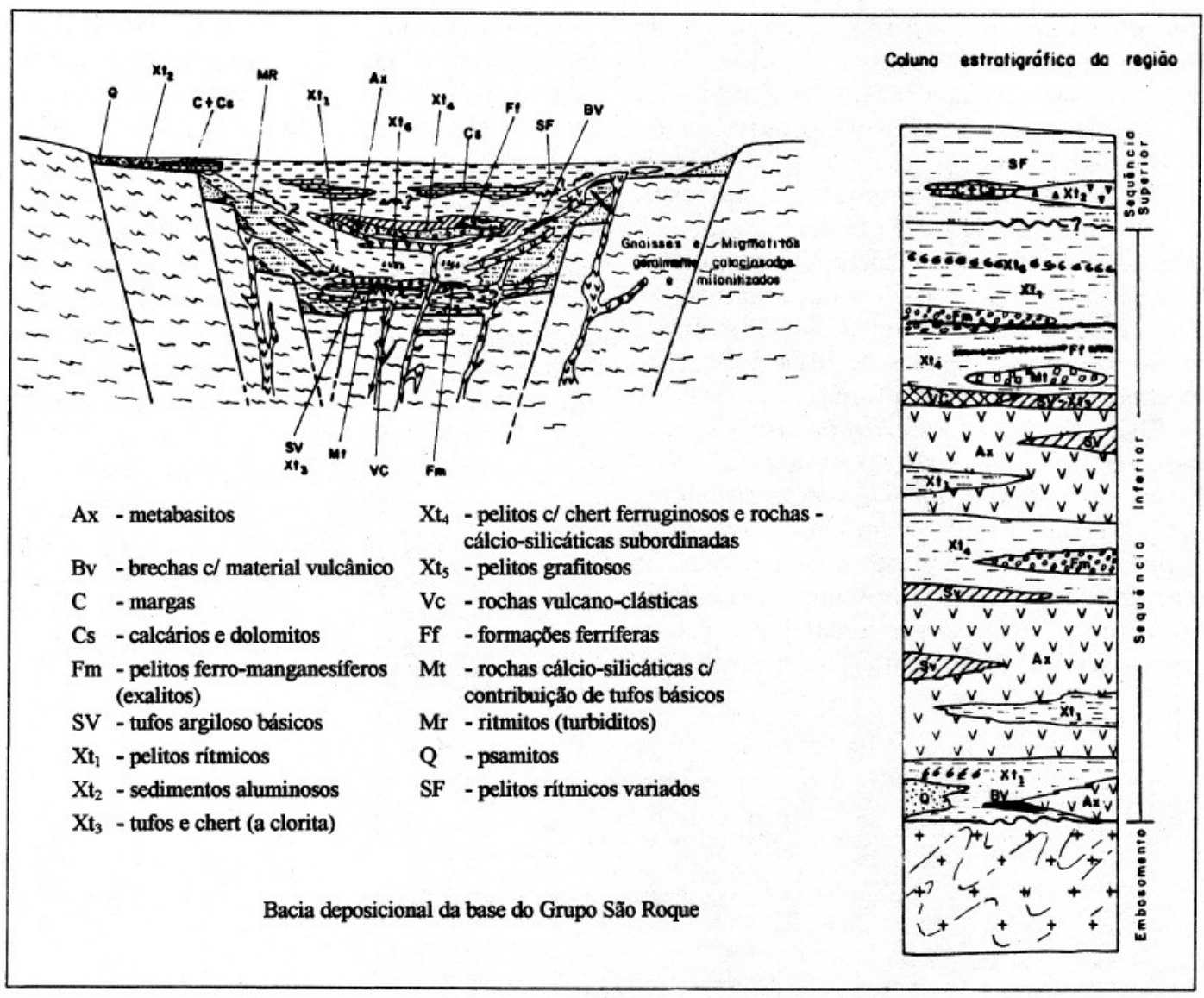

FIGURA 5 - Litoestratigrafia das supracrustais na região da Serra do Itaberaba, segundo JULIANI \& BELJAVSKIS (1983).

Na continuidade das supracrustais a nordeste da Serra do Itaberaba, CAMPOS NETO et al. (1983) definiram uma unidade vulcano-sedimentar basal, com anfibolitos na base e metarritmitos com intercalações de hematita quartzitos, rochas calciossilicáticas e anfibolitos no topo, e uma unidade de metassedimentos rítmi$\cos$, superior, constituída por metarcóseos e metarenitos rítmicos, micaxistos e filitos com intercalações de quartzito (FIGURA 6). A possibilidade da existência de rochas pertencentes a uma conjunto Pré-São Roque na mesma região (que poderia ser o Complexo Embu) foi levantada por CAMPOS NETO \& BASEI (1983).

DANTAS et al. (1984) consideraram que os litotipos existentes na região da folha de Guarulhos (1:50.000) poderiam ser englobados em um pacote basal, com rochas calciossilicáticas, anfibolitos e xistos com intercalações de quartzitos, e em um pacote superior, com xistos finos e intercalações de rochas calciossilicáticas, filitos, metarenitos e anfibolitos. Sobre estes dispor-se-iam metarenitos bandados e filitos laminados com intercala-

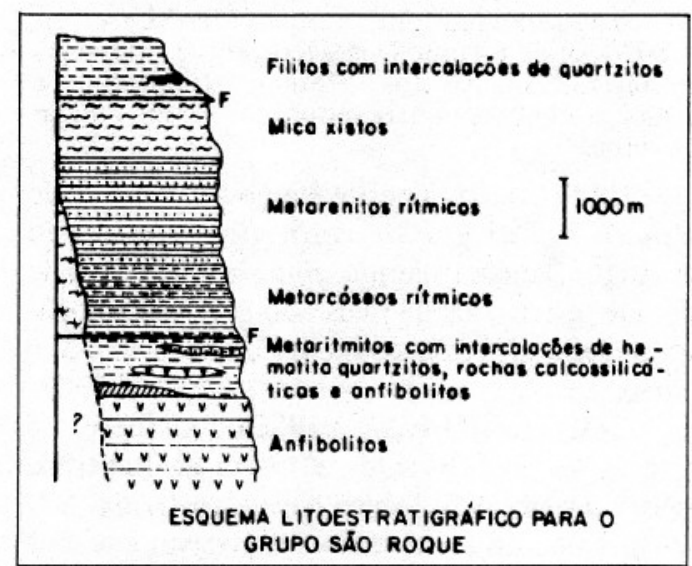

FIGURA 6 - Subdivisão litoestratigráfica na continuidade nordeste da Serra do Itaberaba, segundo CAMPOS NETO et al. (1983).

ções de xistos e quartzitos. DANTAS el al. (1986) propuseram a estes pacotes a hierarquia estratigráfica de formações, respectivamente denominadas, da base para o topo, de 
Jaraguá, Boturuna e Piragibu (FIGURA 7). DANTAS (1990) posicionou cronologicamente o conjunto no Proterozóico Médio e o subdividiu nas unidades Inferior e Superior (FIGURA 8). Também reconheceu corpos de rochas ortognáissicas miloníticas e blastomi- loníticas que pertenceriam ao embasamento do Grupo São Roque, correlacionados aos Grupos Amparo (Unidade Inferior) e Itapira (Unidade Superior) ou ao Complexo Gnáissico-Migmatítico, com idade proterozóica inferior a arqueana.

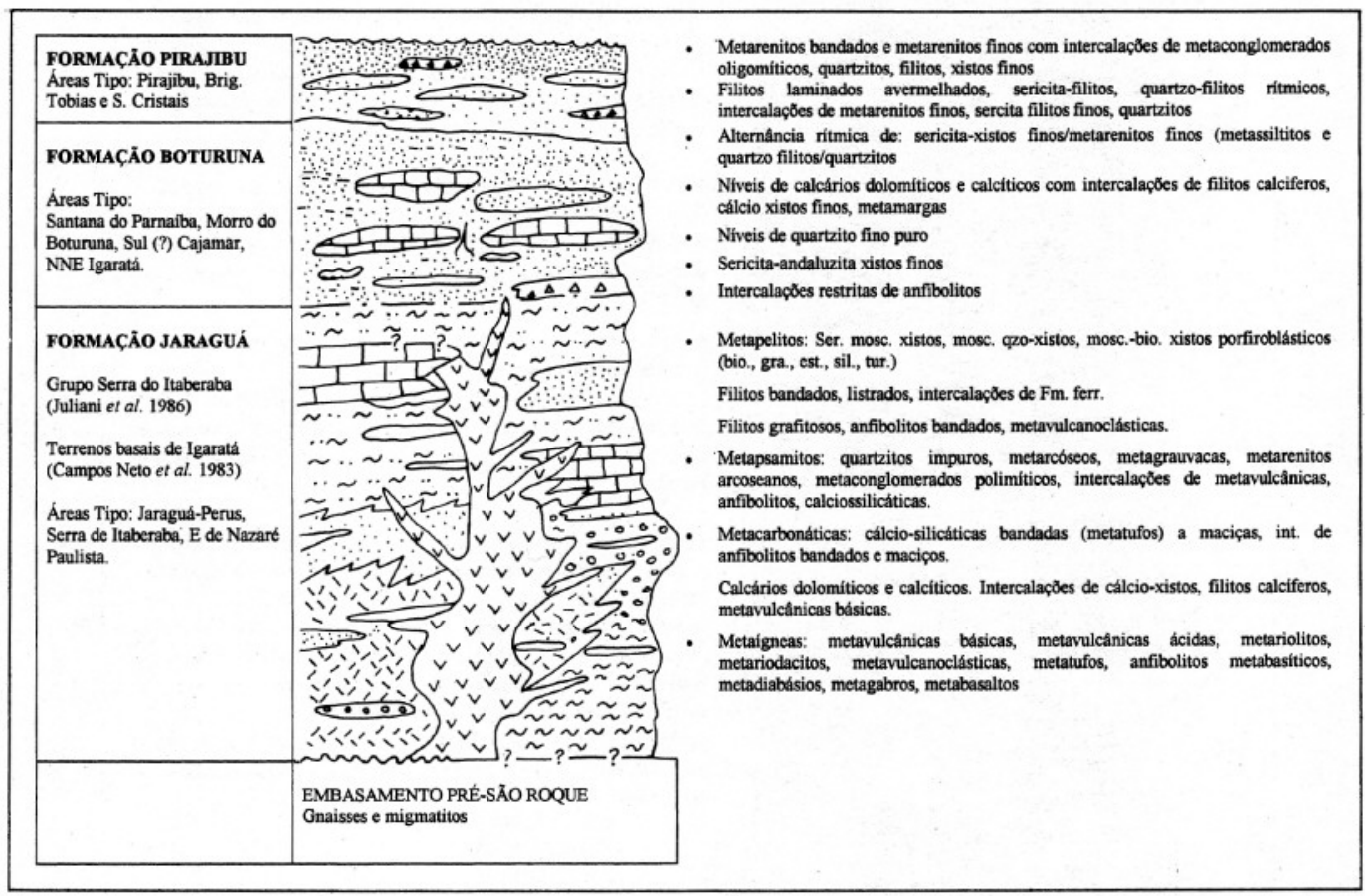

FIGURA 7 - Coluna litoestratigráfica da região da Folha de Guarulhos, proposta por DANTAS et al. (1986).

JULIANI et al. (1986) propuseram que as unidades superior e inferior descritas por JULIANI \& BELJAVSKIS (1983), em essência, constituiriam dois grupos distintos, respectivamente denominados de São Roque (stricto sensu) e Serra do Itaberaba. Foi também sugerido para o primeiro uma evolução no Ciclo Brasiliano, e no Proterozóico Médio a Inferior para o segundo.

Para a mesma área, FRASCÁ et al. (1987) utilizaram a denominação de Seqüência Vulcano-Sedimentar de Itaberaba, que teria sido formado em ambiente do tipo rift, de modo análogo às proposições de JULIANI \& BELJAVSKIS (1983) e de JULIANI et al. (1986), mas não opinaram sobre a idade da seqüência.

Devido à datação dos metariodacitos do Morro do Polvilho (VAN SCHUMUS et al., 1986), o Grupo São Roque passou a ser considerado como depositado no Proterozóico Médio, com evolução até o final do Ciclo Brasiliano. Ao adotar esta concepção cronoestratigráfica, BERGMANN (1988) propôs a sub- divisão do Grupo São Roque, da base para o topo, nas formações Pirapora, com vulcânicas e piroclásticas e um Membro Carbonático (incluindo cálcio-filitos), Estrada dos Romeiros, com os membros Arenoso e Pelítico (constituídos por metapelitos e metapsamitos rítmicos), e Boturuna, com os membros Arcoseano e Ortoquartzítico e dois membros vulcânicos intercalados (FIGURAS 9a a 9d). Estas formações foram redenominadas de Unidade Vulcano-Sedimentar Basal, Unidade Clástica Turbidítica Superior e Unidade Clástica Alóctone por BERGMANN (1991).

SADOWSKI \& TASSINARI (1988) propuseram a alteração do status de Grupo para Complexo São Roque, subdividido no Grupo Itaberaba (basal) e no Grupo São Roque (superior), ambos do Proterozóico Médio. O primeiro corresponderia ao Grupo Serra do Itaberaba e à Formação Pirapora e, o segundo, ao Grupo São Roque de JULIANI et al. (1986) e às formações Estrada dos Romeiros e Boturuna definidas por BERGMANN (1988). 


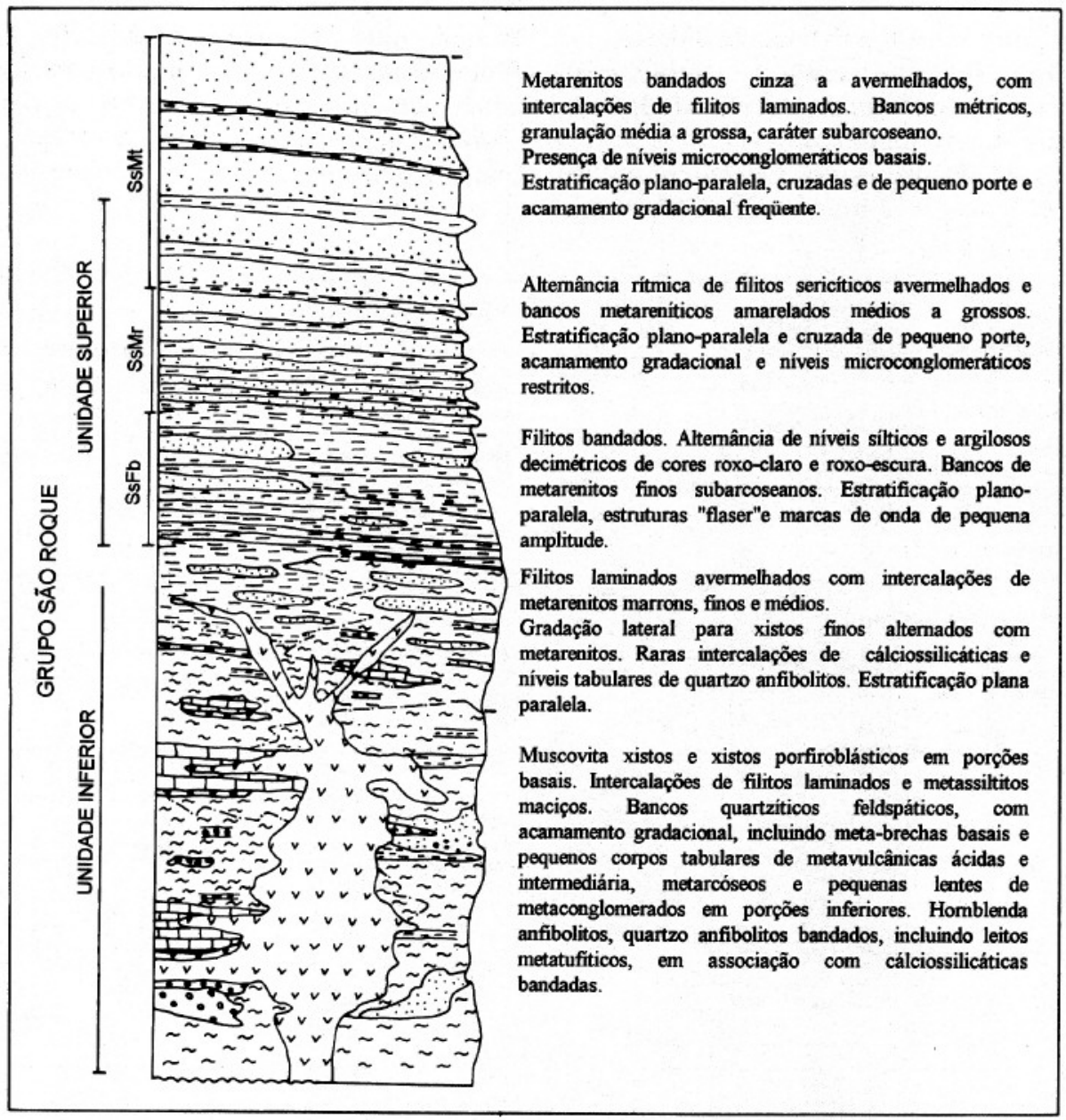

FIGURA 8 - Subdivisão litoestratigráfica da região da Folha de Guarulhos, proposta por DANTAS (1990).

Ao reconhecerem em determinadas unidades geotectônicas do Pré-Cambriano Paulista deformações causadas por um evento de cisalhamento dúctil, considerado como de idade arqueana, HASUI et al. (1988) propuseram separar o conjunto afetado por este evento tectônico sob a denominação de Grupo Ribeira, incluindo aí a região da Serra do Itaberaba, que seria então constituída por uma seqüência vulcano-sedimentar do tipo greenstone belt. Sobre esta unidade situar-se-ia o Grupo São Roque stricto sensu, do Proterozóico Médio.

HASUI et al. (1989) consideraram que as falhas transcorrentes de Taxaquara e Jundiuvira não tinham a propriedade anteriormente assumida de individualizar os grupos Ribeira, Embu, Serra do Itaberaba e Itapira. Como conseqüência propuseram agrupá-los como Supergrupo Ribesita, do Proterozóico Médio ou Médio-Superior, ou até mesmo mais antigo. A denominação de Grupo São Roque foi mantida para a seqüência essencialmente metassedimentar da Faixa, cuja idade da deposição pode- ria ter-se iniciado por volta de $1,0-0,9 \mathrm{Ma}$. O Grupo São Roque comporia, neste contexto, pequenas áreas de metassedimentos, que não puderam ser melhor analisadas quanto à correlação litoestratigráfica, devido à escala regional utilizada nos mapas deste trabalho.

HACKSPACHER et al. (1989) atribuíram a evolução do Grupo São Roque ao Proterozóico Superior, mas consideraram que a sedimentação poderia ter-se iniciado no final do Proterozóico Médio. Os metassedimentos de mais alto grau, aflorantes a norte da Zona de Cisalhamento de Jundiuvira, foram identificados como do Grupo Itapira, do Proterozóico Inferior.

BERGMANN \& McREATH (1992) descreveram a ocorrência de corpos tabulares de metavulcânicas a subvulcânicas amigdaloidais intercaladas nos metarcóseos da Formação Boturuna e os correlacionaram ao corpo de matariodacito do Morro do Polvilho (CARNEIRO, 1983), atribuindo, como conseqüência, idade ao redor de $1,8 \mathrm{Ga}$ para a unidade supe- 
rior do Grupo São Roque. Esta correlação indicaria para os autores que não haveria grandes diferenças de idade entre a unidade vulcanosedimentar basal (Formação Pirapora), que corresponderia ao Grupo Serra do Itaberaba, e as terrígenas do topo (Formação Boturuna) que, desta forma, não justificariam a existência dos dois ciclos geotectônicos sugeridos para a Faixa por JULIANI et al. (1986) e JULIANI (1992).

Na região das folhas de Pirapora, 1:25.000 (HACKSPACHER et al., 1992a) e Cabreúva, 1:50.000 (HACKSPACHER et al., 1992b), verificaram a existência dos grupos Serra do Itaberaba, constituído da base para o topo por mármores, xistos cálcio-silicáticos e xistos com intercalações básicas e quartzitos, e do Grupo São Roque, representado, da base para o topo, pelas formações Estrada dos Romeiros (metassiltitos e metarritmitos), Votoruna (quartzitos e metassiltitos) e Pirapora (metabasitos e calcários). Ambos teriam sido depositados no
Proterozóico Inferior e metamorfisados no Proterozóico Médio-Superior. O contato entre ambos foi verificado ora como discordante, ora como concordante. $\mathrm{O}$ embasamento estaria representado pelos complexos Amparo, Itapira e, possivelmente, Embu, do Proterozóico Inferior a Arqueano.

Na Folha de São Roque, OLIVEIRA et al. (1992b) também mapearam duas áreas dos grupos Serra do Itaberaba e São Roque ao redor do Granito São Roque e, na Folha Japi (1:25.000), OLIVEIRA et al. (1992b) subdividiram o Grupo Itapira, da base para o topo, nas formações Ermida, Japi e Jundiuvira, sobre as quais estaria colocado discordantemente o Grupo Serra do Itaberaba. Sobreporse-ia a este Grupo, de modo concordante, o Grupo São Roque - Formação Estrada dos Romeiros. O quadro evolutivo é o mesmo apresentado por HACKSPACHER et al. (1992a, b).

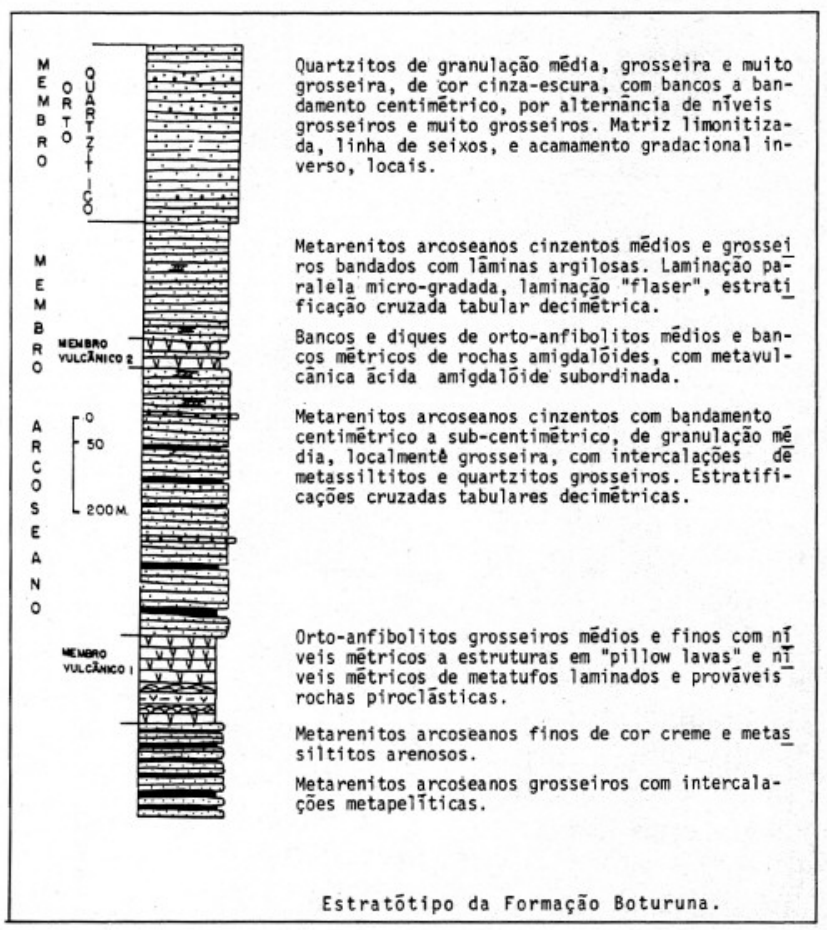

FIGURA 9a - Estratótipo da Formação Boturuna, segundo BERGMANN (1988).

\section{PROPOSTA LITOESTRATIGRÁFICA PARA A REGIÃO DAS SERRAS DO ITABERABA E DA PEDRA BRANCA}

A estratigrafia básica adotada neste trabalho é a de JULIANI et al. (1986), ou seja, con- siderou-se a seqüência metavulcano-sedimentar basal como Grupo Serra do Itaberaba, sobre a qual se despositou o Grupo São Roque stricto sensu. Um esboço geológico da região das serras do Itaberaba e da Pedra Branca, onde foram efetuados estudos mais detalhados, pode ser visto na FIGURA 10. 


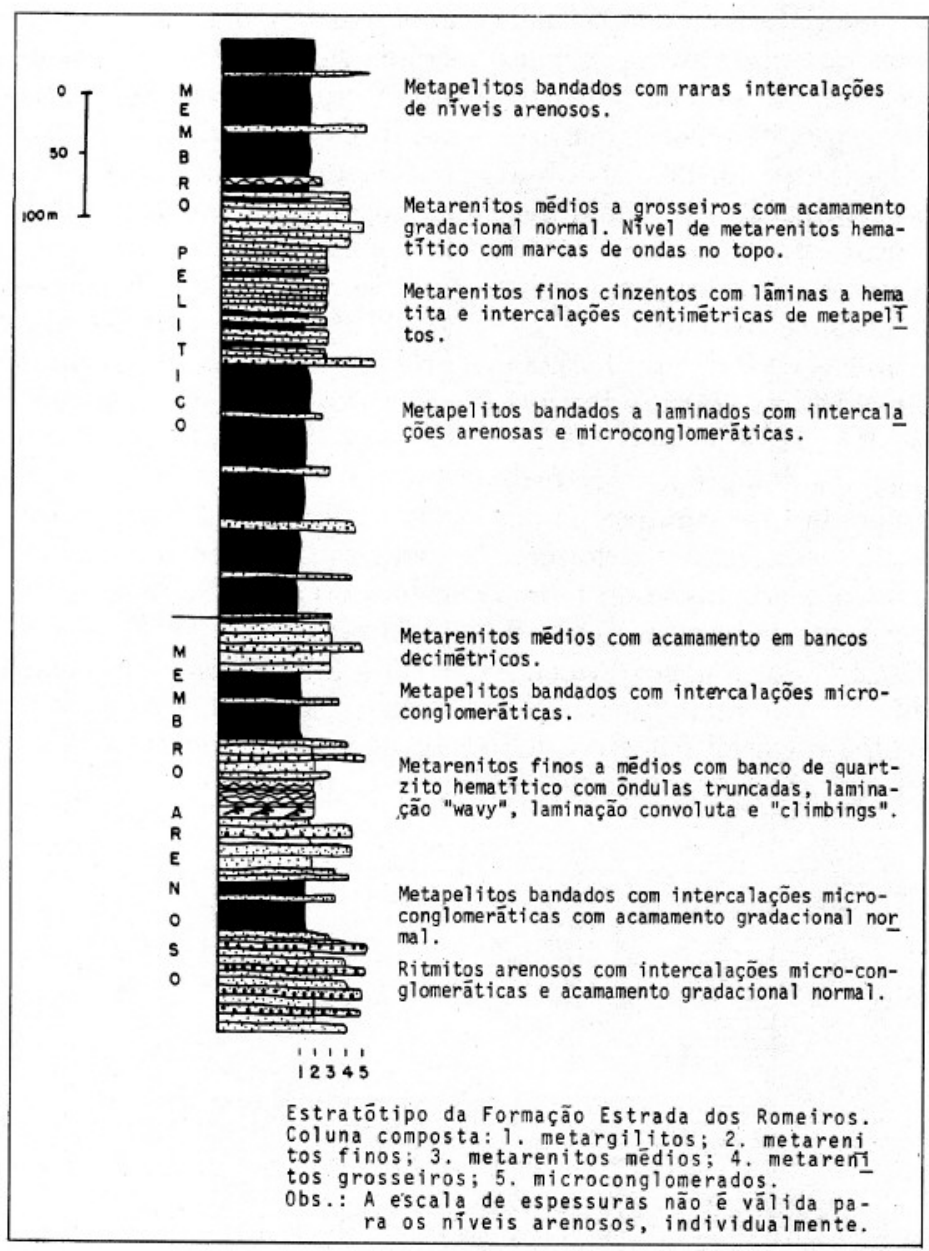

FIGURA 9b - Estratótipo da Formação Estrada dos Romeiros, segundo BERGMANN (1988).

O Grupo Serra do Itaberaba foi subdividido nas formações Morro da Pedra Preta, Pirucaia e Nhanguçu, de acordo com o Guia de Nomenclatura Estratigráfica (PETRI et al., 1986b), ou seja, são unidades litoestratigráficas constituídas por um ou mais tipos de rochas, destacáveis das unidades adjacentes e mapeáveis na escala 1:25.000. Dentro destes critérios, seria ainda possível subdividir estas formações em membros, uma vez que foram cartografados corpos bem definidos e distintos de rochas inseridos nas formações. Entretanto, optou-se por não subdividi-las, especialmente pelas dificuldades encontradas em individualizar com segurança os corpos de metapelitos inferiores e superiores aos derrames básicos da Formação Morro da Pedra Preta. a

A associação de duas ou mais formações, cumprindo os regulamentos do art. B.8, parágrafos $1^{\circ}, 2^{\circ}, 3^{\circ}$ e $4^{\circ}$ do Código Brasileiro de Nomenclatura Estratigráfica (PETRI et al., 1986a) deve ser denominada de Grupo, motivo pelo qual foi adotado este status hierárquico.
Justifica também esta proposta o fato de que diversos autores têm reconhecido que as unidades superiores do Grupo São Roque sensu lato correspondem a uma seqüência deposicional de ambiente sedimentar e geotectônico distinto (IGG, 1947; COUTINHO, 1955; COUTINHO \& TAKEDA, 1955; COUTINHO et al., 1982; JULIANI \& BELJAVSKIS, 1983; CARNEIRO, 1983; DANTAS et al., 1984, 1986; JULIANI et al., 1986; BERGMANN, 1988, 1991; DANTAS, 1990; HACKSPACHER et al., 1992a, b), inclusive tendo alguns destes autores registrado possíveis discordâncias erosivas.

A pendência sobre $o$ hiato de tempo existente entre a deposição dos dois grupos, questão esta ainda não solucionada em função dos poucos dados geocronológicos disponíveis, não é critério restritivo em uma proposta de subdivisão litoestratigráfica, que não deve ser baseada na cronologia relativa das unidades (PETRI et al., 1986a), o que permite as propostas aqui formuladas. 
A seleção dos nomes foi feita em função dos topônimos locais, ou seja: Grupo Serra do Itaberaba, em função da serra ao redor da qual afloram seus litotipos, formações Morro da Pedra Preta, Pirucaia a Nhanguçu, referindo-se às elevações topográficas homônimas, e Grupo São Roque - Formação Piragibu, em concordância com a definição de HASUI et al. (1976) e demais trabalhos já referidos, com modificações.

Segundo o Código Brasileiro de Nomenclatura Estratigráfica, haveria a possibilida- de de agrupar o conjunto das rochas supracrustais em um Supergrupo, mas para tanto seria necessário o estabelecimento de correlações mais seguras entre as formações do Grupo São Roque em outras regiões e a Serra do Itaberaba. Em função da limitada exposição do Grupo São Roque na área estudada, tal agrupamento não foi feito neste artigo, muito embora com a continuidade e a necessária integração dos estudos a hierarquia de supergrupo poderá ainda vir a ser justificada.

\begin{tabular}{|l} 
ESTRATOTIPO DA FORMAÇAO PIRAPORA NO CORPO DE \\
PIRAPORA DO BOM JESUS \\
SECÇAO ESQUEMATICA COMPOSTA
\end{tabular}

FIGURA 9c - Estratótipo da Formação Pirapora no Corpo de Pirapora do Bom Jesus, segundo BERGMANN (1988).

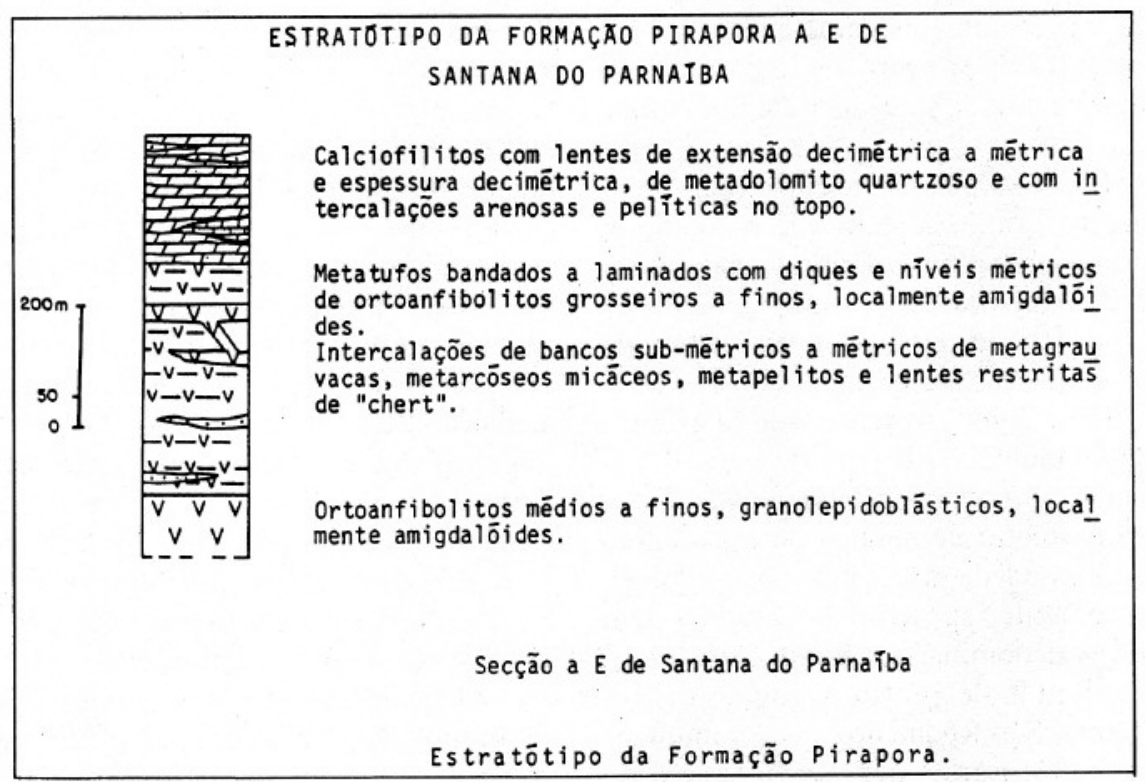

FIGURA 9d - Estratótipo da Formação Pirapora a leste do Santana do Parnaíba, segundo BERGMANN (1988). 


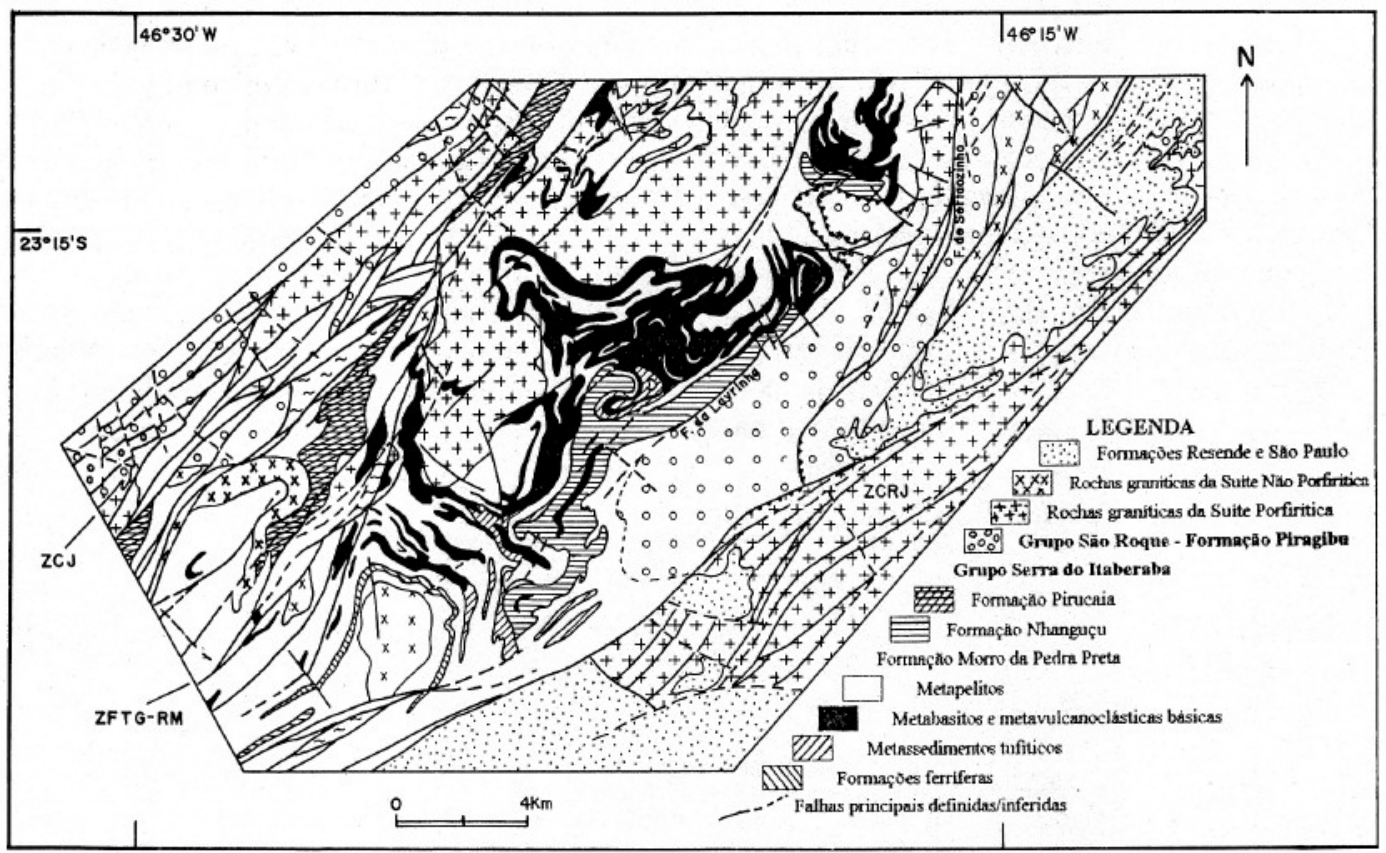

FIGURA 10 - Esboço geológico da região das serras do Itaberaba e da Pedra Branca, onde ZCJ - Zona de Cisalhamento de Jundiuvira, ZCRJ - Zona de Cisalhamento do Rio Jaguari e ZFTG-RM - Zona de Falhas Tanque Grande - Ribeirão dos Macacos. As rochas graníticas que ocorrem na parte central da figura correspondem às serras do Itaberaba (ou do Gil) e Pedra Branca.

Neste contexto, deve-se registrar ainda que o termo Serra do São Francisco (OLIVEIRA, 1889) é prioritário ao São Roque e, portanto, poderia ser adotado para todo conjunto das supracrustais São Roque/Serra do Itaberaba, o que não parece ser recomendável, não somente em face da exposição de rochas graníticas naquela serra, inclusive identificadas por tal nome, como também por ser o nome São Roque amplamente conhecido na comunidade geológica.

Por outro lado, por haver correlações possíveis entre os grupos São Roque e Açungui, como visto nos trabalhos anteriores, poderia ser adotada a denominação de Grupo Açungui, ao invés de São Roque para as supracrustais da Faixa, por ser este o nome mais antigo (OLIVEIRA, 1916), como proposto por MACHADO \& FRAGOSO CÉSAR (1992).

Entretanto, o nome São Roque está consagrado para os metassedimentos de mais baixo grau da faixa estudada, não sendo aconselhável, conseqüentemente, substituí-lo, motivo pelo qual as novas denominações foram acrescentadas aos conjuntos de litotipos que se distinguem do Grupo São Roque do senso comum.

Assim, compõem o Grupo Serra do Itaberaba:

A Formação Morro da Pedra Preta, basal, constituída essencialmente por metabasitos e xistos diversos (parcialmente subjacentes às rochas metavulcânicas), com rochas metavulcanoclásticas, calciossilicáticas, metassedimentos quartzosos e grafitosos, formações ferríferas, rochas metaígneas intermediárias a ácidas, metabasaltos e metatufos alterados hidrotermalmente e metassomatizados pré-metamorfismo (cummingtonita anfibolitos, granada anfibolitos, granada-cordierita-cummingtonita anfibolitos etc.), marunditos (margarita-coríndon xistos), metacherts, metassedimentos ricos em sulfetos e turmalinitos subordinados. $\mathrm{O}$ ambiente deposicional foi vulcano-sedimentar marinho de águas profundas. $\mathrm{O}$ quimismo dos metabasitos indica formação em segmentos normais de cadeias meso-oceânicas, em bacia deposicial semelhante à do Golfo de Aden. As metaintermediárias sugerem origem a partir de subducção ensimática distante, ocasionada pelo fechamento da bacia oceânica, que gerou um ambiente de retro-arco, onde foram depositadas as unidades superiores do Grupo, quais sejam:

A Formação Nhanguçu, colocada concordantemente sobre a anterior, mas com possíveis discordâncias erosivas locais, além de contatos tectônicos. Constitui uma unidade essencialmente clasto-química, com metassedimentos ricos em óxidos-hidróxidos de ferro e manganês (em parte cálcio-silicáticos), xistos finos ricos em andaluzita e com leitos com magneti- 
ta, turmalina ou quatzo (incluindo metacherts) abundantes, algumas lentes de rochas carbonáticas e alguns corpos menores de metabasitos, metavulcanoclásticas básicas e de meta-riólitos. $\mathrm{O}$ conjunto foi depositado em ambiente marinho de águas mais rasas, com pouca atividade vulcânica, podendo ter chegado à exposição dos sedimentos, com formação de evaporitos, sugeridos pela existência de leitos de turmalinitos magnesianos nos metapelitos e de escapolita nas rochas carbonáticas dolomíticas.

A Formação Pirucaia, essencialmente quartzítica, que deve corresponder às fácies marginais da bacia, podendo inclusive ser parcialmente cronocorrelata à Formação Morro da Pedra Preta e à Formação Nhanguçu. Foi provavelmente depositada em ambiente litorâneo.

Sobre o Grupo Serra do Itaberaba está colocado tectonicamente (muito embora não esteja decartada a possibilidade da existência de contatos discordantes) o Grupo São Roque, representado pela Formação Piragibu na região. É constituído predominantemente por metassedimentos rítmicos, em parte arcoseanos, com quartzitos, metabasitos e rochas vulcanoclásticas subordinadas, além de pequenas lentes de metaconglomerados e metabrechas na sua base. $\mathrm{O}$ ambiente deposicional foi de águas rasas, possivelmente marinho, localmente um pouco mais profundas, com pouca atividade vulcânica.

A coluna estratigráfica proposta pode ser vista na FIGURA 11. Trata-se de uma coluna composta obtida a partir de várias secções e afloramentos em acessos secundários e drenagens. Devido à falta de secções geológicas contínuas não houve possibilidade de definição dos estratótipos das formações, como recomendado pelo Código Brasileiro de Nomenclatura Estratigráfica.

\section{CORRELAÇÃO LITOESTRATIGRÁFICA NA FAIXA SÃO ROQUE/ SERRA DO ITABERABA E ARREDORES}

Diversas correlações entre as unidades litoestratigráficas da Faixa São Roque/Serra do Itaberaba têm sido tentativamente propostas, mas as diferenças nas descrições das unidades, e não as semelhanças, são muitas vezes a característica mais marcante.

$\mathrm{Na}$ região das serras do Itaberaba e da Pedra Branca, por exemplo, são encontradas associações de litotipos e alguns tipos de rochas, como xistos com cianita e ricos em andaluzita, marunditos, granada-cordierita-cummingtonita anfibolitos, não descritos em outras partes da Faixa São Roque/Serra do Itaberaba.
Apesar das características próprias de cada uma das regiões estudas em maior detalhe, algumas correlações podem ser feitas entre as unidades litoestratigráficas da região da Serra do Itaberaba e as demais seqüências da Faixa, assim como com os litotipos dos complexos Itapira e Embu, conforme será visto a seguir:

Uma das questões fundamentais é a associação litotípica e a posição litoestratigráfica das sequiências vulcano-sedimentares, uma vez que estes aspectos é que devem justificar a individualização do Grupo Serra do Itaberaba como uma unidade litoestratigráfica maior na região.

De modo geral as seqüências vulcano-sedimentares metamorfisadas têm sido colocadas na base do conjunto das rochas supracrustais da Faixa São Roque/Serra do Itaberaba e correlacionadas à Formação Boturuna de HASUI et al. (1976) pela maioria dos pesquisadores (COUTINHO et al., 1982; CARNEIRO, 1983 e DANTAS, 1990, por exemplo). Freqüentemente as lentes de metaconglomerados polimíticos, como as que afloram no Morro Doce (NNW da cidade de São Paulo), são também incluídos na Formação Boturuna.

Entretanto, no texto da definição original da Formação Boturuna não foram incluídas as rochas metabasíticas, que foram apenas indicadas no desenho da coluna estratigráfica 1 , do Sinclinório de Pirapora (como pode ser visto na FIGURA 3), nem tampouco os metaconglomerados polimíticos, uma vez que foi apenas mencionada a existência de "...pelo menos um conglomerado intraformacional na parte inferior da coluna..."

As rochas vulcânicas (foram citadas pelo menos três ocorrências), os metaconglomerados polimíticos e os metassedimentos da fácies anfibolito foram, de fato, sugeridos como pertencentes ao embasamento do Grupo São Roque.

Assim sendo, as correlações feitas das unidades basais da Faixa com a Formação Boturuna (COUTINHO et al., 1982; CARNEIRO, 1983 e DANTAS, 1990, entre outros autores) somente teriam sido possíveis se a Formação Boturuna tivesse sido completamente redefinida, com a inclusão dos litotipos acima citados, e se fossem revistas as posições estratigráficas relativas das demais unidades, o que não foi feito nestes trabalhos.

HASUI el al. (1976) também incluíram na Formação Boturuna os quartzitos da serra homônima como situados na parte basal do Grupo (com o que concordaram CARNEIRO, 1983 e DANTAS et al., 1986), que BERGMANN (1988) demonstrou não se situarem neste nível estratigráfico, pois estão posiciona- 


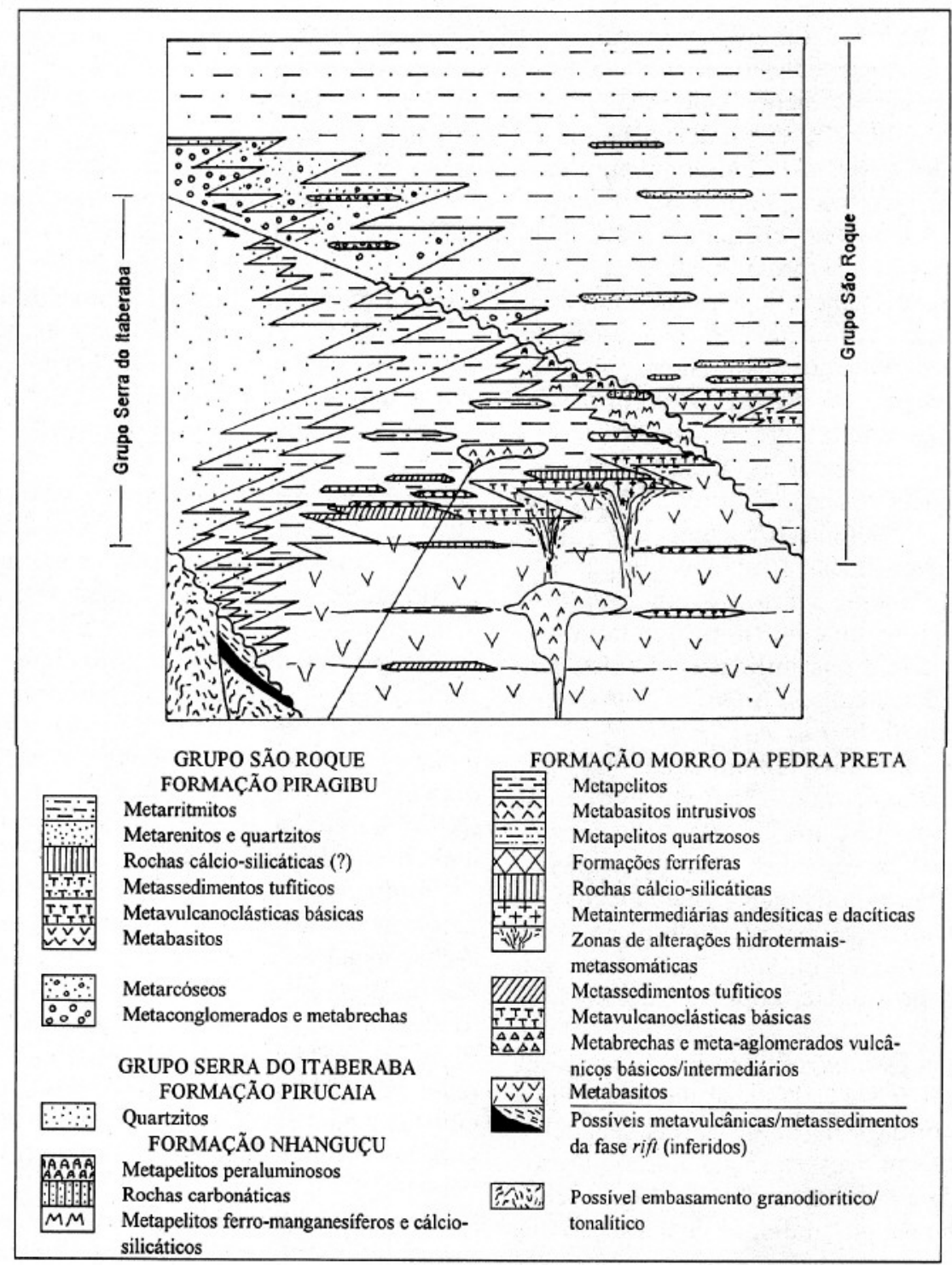

FIGURA 11 - Coluna litoestratigráfica da região das serras do Itaberaba e da Pedra Branca.

dos estratigraficamente acima das seqüências metavulcano-sedimentares, trazendo complicações ainda maiores para estas correlações. A predominância dos metarenitos nas unidades de topo, e não na base das supracrustais sensu lato São Roque, foi também indicada por CAMPOS NETO et al. (1983) na região situada a norte da Serra da Pedra Branca e DANTAS et al. (1990) na região de São Paulo - Mairiporã. Neste último trabalho, inclusive, a unidade predominantemente metarenítica, que pode ser correlacionada à Formação Boturuna, está disposta no topo da unidade superior, sobre um pacote de metarritmitos semelhantes aos da Formação Estrada dos Romeiros.
Por outro lado, as redefinições da Fờmação Boturuna feitas por DANTAS et al. (1986) e BERGMANN (1988) incorporaram parcialmente a proposta litoestratigráfica original de HASUI et al. (1976), ao colocarem as seqüências metavulcano-sedimentares (respectivamente as formações Jaraguá e Pirapora) sob os ritmitos, metarenitos, metapelitos e quartzitos, ou seja, as rochas metavulcânicas básicas comporiam o "embasamento" da Formação Boturuna.

Desta forma, o Grupo Serra do Itaberaba não pode ser correlacionado formalmente com as unidades descritas por HASUI et al. (1976), a não ser parcialmente ao conjunto de litotipos 
sugerido como embasamento do Grupo São Roque, desde que sejam desconsiderados os metaconglomerados na definição original e que sejam incorporados na unidade os litotipos não citados por HASUI et al. (1976), mas presentes na Serra do Itaberaba.

Assim, ao invés de redefinições integrais, parece ser recomendável o abandono do nome Formação Boturuna para as seqüências vulcano-sedimentares basais do Grupo São Roque sensu lato e sua substituição pela denominação Grupo Serra do Itaberaba (JULIANI et al., 1986), por ser este nome prioritário às denominações de Formação Jaraguá (DANTAS et al., 1986), Seqüência Vulcano-sedimentar de Itaberaba (FRASCÁ et al., 1987), Formação Pirapora (BERGMANN, 1988) e Grupo Itaberaba (SADOWSKI \& TASSINARI, 1988).

Conseqüentemente, a utilização do nome Formação Boturuna deve ser feita segundo as concepções litoestratigráficas de DANTAS et al. (1986) e BERGMANN (1988), ou seja, como uma seqüência essencialmente metassedimentar colocada sobre a seqüência metavulcano-sedimentar.

O Grupo São Roque stricto sensu, conforme a redefinição feita neste trabalho para a região das serras do Itaberaba e da Pedra Branca, correlaciona-se, quanto aos litotipos predominantes, parcialmente com a Formação Piragibu de HASUI et al. (1976), mas na região da Serra do Itaberaba ocorrem na sua base metaconglomerados, metabrechas, rochas metavulcânicas e metavulcanoclásticas básicas, inexistentes na definição original. Assim, propõese a redefinição dessa formação a partir das observações feitas naquela região, com a inclusão dos litotipos acima citados. Este novo conjunto comporia parte das porções basais do Grupo São Roque.

A ocorrência de metabasitos na base do pacote de metapelitos de baixo grau foi também observada por SANTORO et al. (1988) na região de Cajamar-Jordanésia. Naquele local este pacote está colocado sobre a unidade de micaxistos e xistos porfiroblásticos da fácies anfibolito mais intensamente deformados, tal qual na Serra do Itaberaba, sugerindo que a Formação Piragibu redefinida pode ter continuidade mais a oeste/sudoeste da Serra do Itaberaba, onde os metabasitos basais e as rochas associadas podem também corresponder à Formação Pirapora do Bom Jesus.

Com relação ao trabalho de COUTINHO et al. (1982), o Grupo São Roque aqui redefinido corresponde à sua unidade superior, indicada no mapa pelo símbolo $\mathrm{P} \in \mathrm{SFr}$, e o Grupo Serra do Itaberaba ao restante da unidade infe- rior. Na concepção de JULIANI \& BELJAVSKIS (1983) as correspondências são, respectivamente, com a Seqüência Superior e com a Seqüência Inferior, excluindo-se da primeira os corpos de rochas carbonáticas e de andaluzita xistos, agora considerados como parte da Formação Nhanguçu, posicionada no topo do Grupo Serra do Itaberaba.

Há também boa correlação, apesar da ausência de vários litotipos, do Grupo Serra do Itaberaba com a Unidade Vulcano-Sedimentar Basal de CAMPOS NETO et al. (1983) e do Grupo São Roque com sua Unidade dos Metassedimentos Rítmicos.

Com os trabalhos de CARNEIRO et al. (1982) e CARNEIRO (1983) as correlações com o Grupo Serra do Itaberaba são dificultadas pelas grandes diferenças nas associações litológicas. No pacote dos Metapsamitos Impuros ocorrem as metavulcânicas, sugerindo poder haver correlações parciais com a Formação Morro da Pedra Preta, mas faltam no Grupo Serra do Itaberaba os corpos de metaconglomerados polimíticos, metarcóseos, metarenitos, metagrauvacas, calcários e rochas metavulcânicas amigdaloidais. Estas grandes diferenças podem, eventualmente, ser devidas a variações das fácies deposicionais entre as porções da bacia representadas nas duas regiões estudadas. Entretanto, os metaconglomerados do Morro Doce, colocados lateralmente às unidades de metavulcânicas/vulcanoclásticas básicas pelos autores, foram verificados como situados sobre elas por JULIANI (1992), o que indica a necessidade de estudos complementares para reconstituição litoestratigráfica desta parte da Faixa, especialmente quanto à possível correlação da seqüência metavulcano-sedimentar com o Grupo Serra do Itaberaba, ao posicionamento relativo dos quartzitos do Pico do Jaraguá, que devem ser correlatos à Formação Boturuna, além dos próprios metaconglomerados, que podem representar a base da Formação Piragibu, como aqui redefinida.

Existe uma possível correlação parcial do pacote dos Metapsamitos Rítmicos e da Unidade dos Metapelitos com o Grupo São Roque, mas também há muitas diferenças de litotipos e de associações.

Outros trabalhos com estratigrafia geral e litotipos semelhantes aos descritos por CARNEIRO (1983) são os de BISTRICHI (1982) e SANTORO (1984).

A associação de litotipos descrita por DANTAS et al. (1984 e 1986) e DANTAS (1990) na região de Guarulhos mostra muita semelhança com os trabalhos anteriormente discutidos. Sua Unidade Inferior (ou Formação 
Jaraguá) corresponderia aos pacotes de Metapsamitos Impuros, Metapelitos, Metamargas e Prováveis Metatufos, mas faltam, entretanto, as rochas calcárias. Os metapsamitos impuros estariam também menos representados na região de Guarulhos-Mairiporã (DANTAS, 1990). A base da Unidade Superior ( $\mathrm{SsFb}$ ), segundo o mesmo autor, corresponde aos filitos rítmicos do topo do pacote metapelítico e o pacote dos Metapsamitos Puros relacionam-se aos metarenitos bandados (SsMt) e aos metarritmitos pelítico-psamíticos (SsMr) da Unidade Inferior, mas sem intercalações de anfibolitos.

DANTAS (1990) considerou sua Unidade Inferior como correspondente ao Grupo Serra do Itaberaba, do qual se destacaria pela maior quantidade de rochas calciossilicáticas, menor quantidade de rochas metavulcanoclásticas e ausência de formações ferríferas. De fato, a correlação é possível mas, ainda assim, não foram descritos em Guarulhos-Mairiporã os litotipos da Formação Nhanguçu (talvez apenas as rochas calciossilicáticas do topo correspondam a parte dela), além de ocorrerem filitos laminados avermelhados e metarenitos marrons, não encontrados na Serra do Itaberaba. A repetição dos litotipos carbonáticos em diversos horizontes também não encontra correspondência na Serra do Itaberaba. A porção basal da seqüência descrita por DANTAS (1990) é semelhante à Formação Morro da Pedra Preta, mas tem bancos de quartzito feldspático com metabrechas basais, metarcóseos e pequenas lentes de metaconglomerados inexistentes na Formação Morro da Pedra Preta. Depreende-se também da análise da coluna litoestratigráfica que as rochas metabasíticas seriam essencialmente intrusivas nos metassedimentos, o que não encontra similaridades no Grupo Serra do Itaberaba, onde predominam rochas metavulcânicas. Estas diferenças podem, entretanto, estar eventualmente relacionadas a variações na paleogeografia da bacia, que se tornaria mais rasa e plataformal no sentido noroeste, ou mesmo devido aos grandes falhamentos que complicaram muito as reconstituições estratigráficas na região de Guarulhos-Mairiporã, segundo DANTAS (1990). Por outro lado, a Unidade Superior guarda grandes semelhanças com o Grupo São Roque, ainda que faltem as metavulcânicas e metavulcanoclásticas básicas e metaconglomerados na base e que ocorram metapsamitos em muito maior quantidade.

A correlação do Grupo Serra do Itaberaba com os trabalhos de BERGMANN (1988, 1991) é mais difícil. A Formação Pirapora ou Unidade Vulcano-Sedimentar Basal, composta por metavulcânicas básicas com lentes de rocha calciossilicáticas no topo, poderia ser correspondente ao Grupo Serra do Itaberaba, mais especialmente à Formação Morro da Pedra Preta. Mas as metavulcânicas da Serra do Itaberaba foram derrames subaquosos extensos, depositados em ambiente marinho de águas relativamente profundas (JULIANI et al., 1986; JULIANI, 1993) e as da Formação Pirapora correspondem a uma ilha vulcânica oceânica. Também ocorrem nesta Formação cálcio-filitos, metarenitos, com estruturas sedimentares de águas rasas e estromatólitos (BETTENCOURT \& LANDIM, 1974; BETTENCOURT \& WERNICK, 1976; BERGMANN, 1988) que compõem parte de biohermas e seus depósitos de tálus das bordas da ilha vulcânica (BERGMANN, 1988; COUTINHO \& LAZZARI, 1989), que não foram encontrados no Grupo Serra do Itaberaba. BERGMANN (1991) afirmou ser o ambiente deposicional de águas marinhas profundas, reconsiderando suas opiniões anteriores, mas uma ilha vulcânica de lavas de composição basáltica estrutura-se sobre uma base de grande diâmetro, o que deveria implicar expressivas variações faciológicas laterais nos arredores, especialmente na Formação Estrada dos Romeiros, como também durante o preenchimento da bacia em geral. Isto não ocorre, sugerindo terem sido as águas rasas (ou seja, formariam um cone de pequena base) cujos condutos poderiam até mesmo cortar os metassedimentos de águas rasas da Formação Estrada dos Romeiros.

Assim, parece ser que a Formação Pirapora representa a atividade vulcânica básica do início da deposição do Grupo São Roque, pobremente ou até mesmo não presente na base da Formação Piragibu na região das serras do Itaberaba e da Pedra Branca e de Cajamar, onde não chegam a constituir uma formação.

As demais unidades descritas por BERGMANN $(1988,1991)$ não têm correspondência com os litotipos do Grupo Serra do Itaberaba e sim com os do Grupo São Roque stricto sensu e com as diversas unidades superiores anteriormente descritas.

A Formação Pirucaia, como aqui definida, não encontra correspondência com as propostas anteriores, exceto parcialmente com a Formação Boturuna de BERGMANN (1988), mas as deformações, o grau e o tipo do metamorfismo indicam que ela faz parte do Grupo Serra do Itaberaba, não se correlacionando com a Formação Boturuna, situada no topo do Grupo São Roque.

JULIANI (1992) observou que os metaconglomerados da parte norte do Morro Doce ocorrem em três camadas distintas intercaladas em 
metarcóseos que gradam para filitos rítmicos no topo. A mais espessa delas tem clastos maiores na base, incluindo blocos com mais de $30 \mathrm{~cm}$ de diâmetro, e as menos espessas, com seixos mais finos, todas elas com granodecrescência ascendente. O conjunto está colocado sobre a sequiência metavulcano-sedimentar em situação semelhante à das partes basais do Grupo São Roque na Serra do Itaberaba. A associação, a gradação e o posicionamento litoestratigráfico dos litotipos é muito semelhante ao observado na região das serras do Itaberaba e da Pedra Branca, sugerindo correspondência entre ambas regiões, ou seja, os metaconglomerados do Morro Doce podem também pertencer à base da Formação Piragibu redefinida.

Os metaconglomerados da Formação Pico de Itapeva, descritos por JULIANI et al. (1990), são muito semelhantes aos do Morro Doce e também gradam para metarcóseos e metapelitos rítmicos. Entretanto, os corpos têm espessuras maiores e estão menos metamorfisados. Também etão colocados discordantemente sobre uma seqüência vulcano-sedimentar, de grau metamórfico e com litotipos semelhantes aos do Grupo Serra do Itaberaba, denominada de cobertura terrígena plataformal do Complexo Embu por SANTORO et al. (1991). A Formação Pico do Itapeva pode eventualmente corresponder, em face da analogia com as regiões do Morro Doce e Serra do Itaberaba, às porções mais externas preservadas da Bacia São Roque.

JULIANI (1992) sugeriu, baseado na associação e estratigrafia dos litotipos e nos graus e tipos de metamorfismo, que as seqüências metavulcano-sedimentares descritas nos blocos geotectônicos adjacentes - incluindo a Unidade dos Xistos Santa Rita (VIEIRA, 1989), o Complexo Embu, com as unidades Rio Una, Rio Paraibuna e Redenção da Serra (FERNANDES, 1991), Complexo Embu (SANTORO et al., 1991; GIMENEZ FILHO et al., 1991; THEODOROVICZ et al., 1991; SILVA et al., 1991), Grupo Itapira (OLIVEIRA et al., 1985; MORALES et al., 1985; OLIVEIRA et al., 1987), além do Grupo São Roque de OLIVEIRA et al. (1983) - podem ser correlacionadas com o Grupo Serra do Itaberaba. A Unidade dos Sericita Xistos e Filitos de VIEIRA (1989) foi, sob o mesmo enfoque, tentativamente correlacionada ao Grupo São Roque.

Tais sugestões de correlações somente são possíveis se for considerado que a estruturação em blocos tectônicos é um evento principalmente tardio ao desenvolvimento dos ciclos geotectônicos (CAVALCANTE \& KAEFER, 1974; OLIVEIRA et al., 1985; BATISTA et al.; 1987; HASUI et al., 1989; JULIANI, 1992, entre outros). A verificação de litotipos do
Grupo São Roque a norte da Zona de Cisalhamento de Jundiuvira (DANTAS, 1990), anteriormente sugerido por SIMÕES et al. (1986), na parte oeste da mesma zona de cisalhamento, embasam também estas correlações. Entretanto OLIVEIRA et al. (1992 a, b,) consideraram que os grupos e complexos situados a norte da zona de cisalhamento de Jundiuvira e a sul das zonas de cisalhamento de Taxaquara Rio Jaguari fazem parte do embasamento dos grupos Serra do Itaberaba e São Roque, estando, portanto, a questão ainda em aberto.

Com relação ao Grupo Serra do Itaberaba cartografado por HACKSPACHER et al. (1992) a, b) e OLIVEIRA et al. (1992 a, b), os mármores e xistos calciossilicáticos se dispõem na base do pacote e há intercalações de rochas básicas e quartzitos no topo da seqüência, o que o distingue da definição original. Entretanto esta associação de litotipos pode representar diferentes fácies deposicionais da bacia Serra do Itaberaba, já fora do domínio oceânico profundo, podendo a associação corresponder a variações laterais das formações Nhanguçu e Pirucaia. Já para as formações do Grupo São Roque, há total inversão da estatigrafia em relação à proposta de BERGMANN (1988) e, uma vez que as propostas foram feitas para áreas próximas, necessita-se de estudos complementares para resolução desta questão mas, eventualmente, pode haver inversões litoestratigráficas causadas por dobramentos ou por zonas de cisalhamento de baixo ângulo.

Muito embora as idades dos grupos Serra do Itaberaba e São Roque não sejam critérios limitantes para a separação litoestratigráfica proposta, elas são fundamentais no entendimento da evolução da Faixa.

As correlações feitas por BERGMANN \& McREATH (1992) entre as metavulcânicas da Serra do Boturuna e as do Morro do Polvilho implicam considerar-se todo pacote de rochas supracrustais como tendo sido depositado no início do Proterozóico Médio.

Devido à importância desta correlação para evolução geológica e para litoestratigrafia da Faixa, são necessárias algumas considerações adicionais sobre o tema (discussões mais completas sobre o assunto e sobre a geocronologia podem ser encontrados no trabalho de JULIANI, 1993), quais sejam:

As rochas do Morro do Polvilho descritas por CARNEIRO (1983) são porfiríticas (com fenocristais de plagioclásio e de feldspato potássico entre 0,5 e $1,0 \mathrm{~cm}$ de comprimento em moda), têm abundante quartzo na matriz fanerítica fina e têm composição variando de riodacítica a riolítica, ao passo que as rochas do Morro 
do Boturuna são faneríticas finas a afaníticas, amigdaloidais, com quartzo apenas como acessório, cuja composição não pode ser determinada devido às alterações hidrotermais/intempéricas, mas à pequena quantidade de quartzo e abundância de caulim, sugerem composição tendendo a traquitíca. As composições mineralógicas, texturas e estruturas indicam, desta forma, tratar-se de rochas ígneas diferentes, cristalizadas em distintos níveis crustais e afetadas por diferentes processos pós-metamórficos.

CARNEIRO (1983) posicionou os metariodacitos/riólitos na sua unidade basal (Metapsamitos Impuros) e os interpretou como intrusivos. BERGMANN \& McREATH (1992) consideraram as rochas do Morro do Polvilho como encaixados na unidade superior (Formação Boturuna) do Grupo São Roque e, pelo menos em parte, efusivas.

Além do mais, CARNEIRO (1983) definiu os metariodacitos do Morro do Polvilho como intrusões sin-metamórfico-deformacionais (F1), dificultando ainda mais as correlações feitas por BERGMANN \& McREATH (1992). Inclusive, sendo os metariodacitos sin-F1, o significado da idade de 1,8 Ga dos metariodacitos do Morro do Polvilho, que a maioria dos pesquisadores considera como representando o início da deposição do Grupo São Roque (incluindo aí o Grupo Serra do Itaberaba), torna-se impossível à luz dos dados de CARNEIRO (1983).

As discrepâncias apresentadas parecem impossibilitar, ao nível do conhecimento atual, tais correlações, não podendo, portanto, ser utilizadas como critério para inclusão em uma mesma unidade litoestratigrafia os grupos Serra do Itaberaba e São Roque.

Segundo TASSINARI et al. (1985), os seixos graníticos dos metaconglomerados do Morro Doce forneceram idade $\mathrm{Rb} / \mathrm{Sr}$ de $1200 \pm$ $75 \mathrm{Ma}$, o que pode indicar o período do início da deposição do Grupo São Roque, ou seja, considerando-se estes dados conjuntamente com os do metariodacito do Morro do Polvilho, pode-se concluir pela existência de dois ciclos deposicionais, corroborando a separação dos grupos Serra do Itaberaba e São Roque.

Para concentrados de plagioclásio de metabasitos de Pirapora do Bom Jesus, TASSINARI (1988) obteve idades $\mathrm{K} / \mathrm{Ar}$ de $1652 \pm 121 \mathrm{Ma} \mathrm{e}$ $1053 \pm 96 \mathrm{Ma}$. Caso a idade esteja correta, a Formação Pirapora do Bom Jesus deverá ser correlacionável ao Grupo Serra do Itaberaba ou, se prevalecer a idade mais nova, a correspondência aqui proposta pode ser a mais coerente.

As correlações efetuadas estão sintetizadas na FIGURA 12.

\section{(A)}

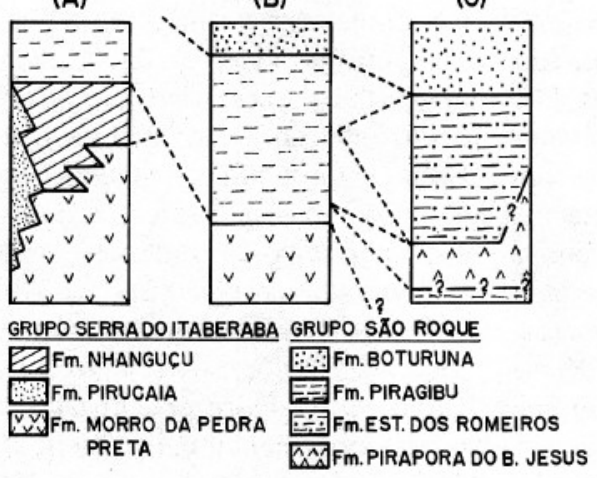

FIGURA 12 - Síntese das correlações litoestratigráficas da Faixa São Roque/ Serra do Itaberaba, onde $(\mathrm{A})$ corresponde à região das serras do Itaberaba e da Pedra Branca; (B) à região do Pico do Jaraguá - Morro Doce; (C) à região de Pirapora do Bom Jesus - Serra do Boturuna.

\section{CONCLUSÕES}

Muitos autores consideram que o termo "Série de Assunguy" foi proposto por DERBY (1878) e o nome São Roque por GONZAGA DE CAMPOS (1889), ao referir-se às camadas de São Roque com conotação litoestratigráfica, interpretações estas não confirmadas nesta revisão.

O nome prioritário para as supracrustais de baixo grau metamórfico nos estados de São Paulo e do Paraná seria Série da Serra do São Francisco (OLIVEIRA, 1889) e as primeiras citações da Série de Açungui devem-se a OLIVEIRA (1916) e de Série de São Roque a OLIVEIRA (1925).

Haveria, desta forma, a possibilidade formal de renomear o Grupo São Roque stricto sensu (e até mesmo o Grupo Açungui) como Grupo Serra de São Francisco, ou até mesmo como Grupo Açungui. Entretanto, parece ser mais adequado não promover tal redefinição devido ao fato de ser o nome Grupo São Roque já consagrado na comunidade geológica.

Há atualmente uma série de dificuldades para o estabelecimento de colunas litoestratigráficas para a Faixa Serra do Itaberaba/São Roque que podem ser atribuídas aos seguintes fatos: a maioria das áreas estudadas em detalhe são relativamente restritas, as escalas dos trabalhos são geralmente pequenas, faltam algumas das fácies deposicionais e/ou vulcânicas em determinadas regiões, a ocorrência de variações faciológicas regionais, a existência de complexidades estruturais e de diversas 
zonas de cisalhamento que cortam a região, que destroem as estruturas e a estratigrafia e justapõem diferentes unidades litoestratigráficas.

Entretanto, a revisão aqui efetuada permite algumas contribuições, quais sejam:

a) Devem ser abandonadas as denominações de Formação Boturuna (e não Voturuna, como considerado por alguns autores), Formação Jaraguá, Seqüência Vulcano-sedimentar de Itaberaba e Grupo Itaberaba (do Complexo São Roque) para as seqüências vulcano-sedimentares basais por haver, respectivamente, dificuldades de correlações entre as definições originais e as atualmente verificadas; devido à prioridade da denominação Grupo Serra do Itaberaba; e pela impropriedade do termo Complexo, uma vez que as supracrustais são passíveis de subdivisões em formações e até mesmo em membros.

b) Termos como unidades Inferior e Superior podem, conseqüentemente, ser substituídos e/ou associados às formações. Apesar das definições atuais ainda carecerem de estudos complementares, as unidades definidas como metapsamitos rítmicos, metarenitos rítmicos, por exemplo, poderão, possivelmente, ter status de membros, de modo análogo ao apresentado por BERGMANN (1988)

c) Nomes com conotações genéticas, como Unidade Clástica Turbidítica Superior, metamargas e prováveis metatufos etc., também não devem ser utilizados, por serem, muitas vezes, resultado de interpretações que podem, obviamente, ser alteradas, o que implicaria renomeações e por não estarem em acordo com as formalidades do Código Brasileiro de Nomenclatura Estratigráfica.

d) A denominação Formação Boturuna deve ser utilizada segundo a redefinição de BERGMANN (1988), ou seja, posicionada no topo do Grupo São Roque, a não ser que seja comprovada como em posição normal a coluna estratigráfica indicada por HACKSPACHER et al. (1992a, b).

e) A denominação Formação Piragibu (como definida, e não Pirajibu) deve ser aplicada incluindo a redefinição de JULIANI (1993), devendo ainda serem estudadas as possíveis correlações com a Formação Estrada dos Romeiros, que podem representar diferentes fácies do ambiente deposicional.

f) $\mathrm{O}$ nome Formação Pirapora deve ser substituído por Formação Pirapora do Bom Jesus, por ser esta a toponímia correta e por já haver em outras regiões do país unidade litoestratigráfica denominada de Formação Pirapora. Esta formação pode, pelo menos em parte, ter sido gerada por intrusões sin-deposicionais à Formação Estrada dos Romeiros.

g) Ao nível do conhecimento atual o Grupo Serra do Itaberaba pode ser subdividido nas formações Morro da Pedra Preta, Pirucaia e Nhanguçu e Grupo São Roque nas formações Piragibu, Pirapora do Bom Jesus, Estrada dos Romeiros e Boturuna, passíveis de subdivisões em membros, como discutido por BERGMANN (1988). A Formação Piragibu pode ser cronocorrelata à Formação Pirapora do Bom Jesus, por sua vez recoberta pela Formação Estrada dos Romeiros, que deve interdigitar-se com a Formação Piragibu (FIGURA 12). Ambas estão recobertas pela Formação Boturuna.

h) As unidades litoestratigráficas aqui analisadas podem ser reconhecidas além das zonas de cisalhamento que as limitaram nas definições originais, como reconhecido por diversos autores, o que possibilita correlações, como as efetuadas preliminarmente por JULIANI (1992). Neste contexto, sugerimos que associações litoestratigráficas semelhantes com litotipos em situações geológicas similares, afetadas por deformações e tipos de metamorfismo semelhantes, por exemplo, devem ser tentativamente correlacionadas, evitando-se novos nomes e, especialmente, não devem ser consideradas de evoluções geotectônicas distintas até que sejam provadas as possíveis diferenças, para evitar-se proliferação de nomes, como evidenciado na revisão da Faixa São Roque/Serra do Itaberaba. Consideramos este aspecto especialmente válido para as associações de rochas supracrustais do Grupo Itapira e complexos Embu e Paraíba do Sul, já que são mencionados como correlacionáveis aos grupos Serra do Itaberaba, São Roque e Açungui.

Consideramos ainda que há muito trabalho a ser feito na Faixa São Roque/Serra do Itaberaba até que sua litoestratigrafia esteja bem conhecida, devendo, desta forma, as considerações aqui apresentadas serem encaradas como base e orientação para as pesquisas futuras. Para tanto ainda mais adequado seria a constituição de um grupo de trabalho coordenado por uma das entidades científicas para equacionamento dos problemas e consolidação dos resultados.

\section{AGRADECIMENTOS}

Agradecemos à Prof ${ }^{a}$ Magda Bergmann pela criteriosa revisão do texto e pelas diversas sugestões apresentadas, que muito melhoraram o conteúdo e a clareza do trabalho, apesar de defender proposições litoestratigráficas distintas das aqui formuladas. 
Aos revisores anônimos, expressamos nossos agradecimentos pelas valiosas críticas e correções apresentadas, que contribuíram significativamente para melhoria do trabalho.

Gostaríamos ainda de solicitar aos leitores sugestões e correções às formulações aqui efetuadas, para aprimoramento da subdivisão da litoestratigrafia da Faixa Serra do Itaberaba/São Roque, às quais antecipadamente agradecemos.

\section{REFERÊNCIAS BIBLIOGRÁFICAS}

ALGARTE, J.P.; CUNHA, H.C. da S.; DAITX, E.C.; CHIEREGATI, L.A.; CAVALCANTE, J.C. 1974. Geologia da Folha de S. Paulo (parcial). In: CONG. BRAS. GEOL., 28, Porto Alegre, 1974. Anais..., Porto Alegre, SBG, v. 4, p. 339-357.

BARBOSA, O. 1936a. Contribuição ao conhecimento das formações pré-devoneanas no Brasil. Min. e Metal., 1(1): 21-23.

1936b. Contribuição ao conhecimento das formações pré-devoneanas no Brasil. Min. e Metal., 1(4): 170-172.

BATISTA, J.J. et al. 1987. Geologia das Folhas Cajamar e Jordanésia (1:25.000) - Relatório Final. São Paulo, IGCE UNESP/PRÓ-MINÉRIO, 2v., 142p.

BERGMANN, M. 1988. Caracterização estratigráfica e estrutural da seqüência vulcano-sedimentar do Grupo São Roque na região de Pirapora do.Bom Jesus, Estado de São Paulo. São Paulo, 155p. (Diss. Mest. apres. ao IGUSP).

1991. Litoestratigrafia e paleoambiente do Grupo São Roque na região de Pirapora do Bom Jesus. In: JORN. CIENT., São Paulo, 1990. São Paulo, USP, Bol. IGUSP, Publ. Esp., 9, p. 107-109.

\& McREATH, I. 1992. Rochas vulcânicas do Grupo São Roque na região do Morro Boturuna em São Paulo. In: JORN. CIENT., 2, São Paulo, 1992. Bol. IGUSP. Public. Esp., 12, p. 19-21.

BETTENCOURT, J.S. \& LANDIM, P.M.B. 1974. Estudo geoquímico de óxidos e elementos traços de rochas calcárias do Grupo Açungui pela análise fatorial. In: CONG. BRAS. GEOL., 27, Porto Alegre, 1974. Anais..., Porto Alegre, SBG, v.7, p. 153-160.

; \& WERNICK, E. 1976. Contribuição à geoquímica do $\mathrm{Sr}$ das rochas calcárias dos grupos São Roque e Açungui (SP, PR). In: CONG. BRAS. GEOL., 29, Ouro Preto, 1976. Anais..., Ouro Preto, SBG, v. 1, p. 171-187.

BISTRICHI, C.A. 1982. Geologia do Sinclinório de Pirapora, SP. São Paulo, 92p. (Diss. Mest. apres. ao IGUSP).
BISTRICHI, C.A.; CARNEIRO, C.D.R.; DANTAS, A.S.L.; PONÇANO, W.L.; CAMPANHA, G.A. da C.; NAGATA, N.; ALMEIDA, M.A.; STEIN, D.P.; MELO, M.S. de; CREMONINI, O.A. 1981. Mapa Geológico do Estado de São Paulo, escala 1:500.000. São Paulo, IPT/PRÓ-MINÉRIO, v.2 (IPT, Monogr. 6).

BRANNER, J.C. 1919. Mappa Geológico do Brazil (1919) - Escala 1:5.000.000 e texto explicativo. Geol. Soc. Am.

CAMPOS NETO, M. da C. \& BASEI, M.A.S. 1983. Importância dos falhamentos transcorrentes na configuração do PréCambriano entre São José dos Campos e Amparo.. In: SIMP. REG. GEOL., 4, São Paulo, 1983. Atas..., São Paulo, SBGNSP, p. 79-90.

; BASEI, M.A.S.; ARTUR, A.C.; SILVA, M.E. da; MACHADO, R.; DIAS NETO, C. de M.; FRAGOSO-CÉSAR, A.R.; SOUZA, A.F. 1983. Geologia das folhas de Igaratá e Piracaia. In: JORN. SOBRE A CARTA GEOL. DO EST. DE S. PAULO EM 1:50.000, 1, São Paulo. Atas..., São Paulo, SICCT/PRÓ-MINÉRIO, p. 55-79.

CARNEIRO, C.D.R. 1983. Análise estrutural do Grupo São Roque na faixa entre o Pico do Jaraguá e a Serra dos Cristais, $S P$. São Paulo, 155p. (Tese de Dout. apres. ao IGUSP).

; DANTAS, A.S.L.; SUEMITSU, A.; VASCONCELLOS, A.A.B.C. de; LIMA, M.O. de. 1982. Análise estrutural do Grupo São Roque na faixa entre o Pico do Jaraguá e a Serra dos Cristais (SP). São Paulo, IPT/PRÓ-MINÉRIO, 100p. (IPT, Relatório 17.855).

CAVALCANTE, J.C. \& KAEFER, L.Q. 1974. Geologia da Folha de Santos (parcial). In: CONG. BRAS. GEOL., 28, Porto Alegre, 1974. Anais..., Porto Alegre, SBG, v.4, p.227-245.

COUTINHO, J.M.V. 1955. Sobre o meta-conglomerado dos arredores de São Paulo. Eng., Min. Met., 21(121): 15-16. 
1968a. O Grupo Açungui nas vizinhanças da capital de São Paulo. In: CONG. BRAS. GEOL., 22, Belo Horizonte, 1968. Res. das Com.. Belo Horizonte, SBG, p. 2.

1968b. Petrologia do Pré-cambriano em São Paulo e arredores. São Paulo, 174 p. (Tese de Cátedra apresentada à Faculdade de Filosofia, Ciências e Letras da Universidade de São Paulo).

1971a. Estado atual de conhecimento do Pré-Cambriano Superior sulbrasileiro; uma síntese. In: CONG. BRAS. GEOL., 25, São Paulo, 1971. Anais..., São Paulo, SBG, v.1, p. 8392.

1971b. Geologia da área Guarulhos-Arujá, S.P. An. Acad. Bras. Ciênc. 43(3/4): 836-837.

\& TAKEDA, F.K. 1955. Metaconglomerado e rochas associadas no município de São Paulo. São Paulo, USP, Bol. Fac. Fil., Ciênc. e Letr. (186): 5-56. (Min., 13).

; \& LAZZARI, M. de L. 1989. Petrology of a proterozoic volcano in São Paulo, Brazil. In: INTERN. GEOL. CONG., 28, Washington, 1989. Abstracts..., Washington, IUGS, v.1, p. 335.

; RODRIGUES, E. de P.; SUEMITSU, A.; JULIANI, C.; BELJAVSKIS, P.; PEROSA, P. de T.Y. 1982. Geologia e petrologia da seqüência vulcano-sedimentar do Grupo São Roque na Serra de Itaberaba - SP. In: CONG. BRAS. GEOL., 32, Salvador, 1982. Anais..., Salvador, SBG, v.2, p. 624640.

DANTAS, A.S.L. 1990. Geologia da faixa São Roque e intrusivas associadas na região entre São Paulo e Mairiporã, Norte de São Paulo - SP. São Paulo, 199p. (Diss. Mestr. apres. ao IGUSP).

; TEIXEIRA, A.L.; BISTRICHI, C.A. 1984. Geologia da Folha Guarulhos na escala 1:50.000. São Paulo, IPT/PRÓ-MINÉRIO, 5v., 195p. (IPT, Rel. 20.646).

; ALMEIDA M.A. de; TEIXEIRA, A.L.; NAGATA, N.; BISTRICHI, C.A. 1986. Integração geológica das folhas de Guarulhos e Santana do Parnaíba na escala 1:50.000. In: JORN. SOBRE A CARTA GEOL. DO EST. DE
S. PAULO EM 1:50.000, 2, São Paulo, 1986. Atas..., São Paulo (no prelo).

DERBY, O.A. 1878. Geologia da região diamantífera da Província do Paraná no Brasil. Arch. Museu Nac., (3): 89-96.

1909. Estudios Geologicos en el Brasil. In: CONG. PANAMER., 1, Santiago, Chile, 1909. CONG. CIENT., 4, v. 11, p. 498-507.

FERNANDES, A.J. 1991. O Complexo Embu no leste do Estado de São Paulo: contribuição ao conhecimento da litoestratigrafia e da evolução estrutural e metamórfica. São Paulo, 120p. (Diss. Mes. apres. ao IGUSP).

FRASCÁ, M.H.B. de O.; COUTINHO, J.M.V.; RODRIGUES, E. de P.; FIGUEIREDO, M.C.H. de; ZAINE, J.E.; BRAGA, T. de O. 1987. Estudo petrográfico-litoquímico da seqüência vulcano-sedimentar de Itaberaba - SP. In: SIMP. REG. GEOL., 6, Rio Claro, 1987. Anais..., Rio Claro, SBG, v.11, p. 63-81.

GIMENEZ FILHO, A.; MACHADO JR., D. de L.; ZAINE, J.E.; FRASCÁ, M.H.B. de O. 1991. Geologia das folhas Jacaré, Tremembé, Taubaté e Pindamonhangaba - SP. Parte 2: Embasamento meridional da Bacia de Taubaté. In: SIMP. GEOL. SUD., 2, São Paulo, 1991. Bol. de Res. São Paulo, SBG-NSP/NRJ, p. 46-47.

GOMES, C. de B. 1971. Polimetamorfismo dos anfibolitos do Jaraguá, São Paulo: evidências químicas, mineralógicas e texturais. São Paulo, 99 p. (Tese de LivreDoc. apres. ao IGUSP).

DUTRA, C.V.; OOSTERWYCK-GASTUCHE, M.C. VAN. 1968. Variações químicas nas hornblendas do corpo anfibolítico do Jaraguá, SP. In: CONG. BRAS. GEOL., 22, Belo Horizonte, 1968. Res. Com. Belo Horizonte, SBG, p. 4-5.

GONZAGA DE CAMPOS, L.F. 1889. Secção Geológica: In: DERBY, O.A. (1889) Relatório 1888. Comm. Geog. Geol. da Prov. de S. Paulo, p. 21-34.

1925. Relatório do Serviço Geológico - Anno de 1923. Serv. Geol. e Min. do Brasil, 217p.

GUIMARÃES, D. 1936. Quadro chrono-geológico do Brasil. Min. e Met. 1 (2): 65-71.

GUIMARÃES, D. 1964. Geologia do Brasil, Rio de Janeiro, MME-DNPM/DFPM, Mem. $N^{\circ}$ 1, 674p. (Publ. $N^{\circ} 323$ ) 
HACKSPACHER, P.C.; GODOY, A.M.; OLIVEIRA, M.A.F. de 1992a. Geologia da Folha Pirapora, SP em 1:25.000. In: CONG. BRAS. GEOL., 37, São Paulo, 1992. Bol. Res. Exp., SBG, São Paulo, v. 2, p. $127-128$.

; OLIVEIRA, M.A.F. de; GODOY, A.M. 1992b. Geologia dos grupos Serra do Itaberaba/São Roque na Folha Cabreúva-SP, 1:50.000. In: CONG. BRAS. GEOL., 37,. São Paulo, 1992. Bol. Res. Exp.., SBG, São Paulo, v. 2, p. 124-125.

; OLIVEIRA, M.A.F. de; GODOY, A.M.; VALERIANO, C. de M. 1989. A geologia dos grupos Itapira e São Roque na região de Cabreúva; uma revisão. In: SIMP. GEOL. SUD., 1, Rio de Janeiro, 1989. Bol. Res. . Rio de Janeiro, SBG/NRJ-NSP, p. 93-94.

HASUI, Y. 1973. Tectônica da área das folhas de São Roque e Pilar do Sul. São Paulo, 134p. (Tese de Livre-Doc. apres. ao IGUSP).

1975a. Evolução polifásica do Pré-Cambriano a oeste de São Paulo. São Paulo, USP, Bol. IG (6): 95-108.

1975b. Geologia da Folha de São Roque. São Paulo, USP, Bol. IG (6): 157-183.

1981. Mapa de Jazidas e Ocorrências Minerais do Estado de São Paulo (Texto Explicativo). São Paulo, IPT/PRÓ-MINÉRIO, v. 1, 349 p. (IPT, Monogr. 4).

; CARNEIRO, C.D.R.; BISTRICHI, C.A. 1978. Os granitos e granitóides da Região de Dobramentos Sudeste nos estados de São Paulo e Paraná. In: CONG. BRAS. GEOL., 30, Recife, 1978. Anais..., Recife, SBG, v.6, p. 2594-2608. ; PENALVA, F.; HENNIES, W.T. 1969. Geologia do Grupo São Roque. In: CONG. BRAS. GEOL., 23, Salvador, 1969. Anais..., Salvador, SBG, p. 101-134.

; SADOWSKI, G.R; CARNEIRO, C.D.R. 1976. Considerações sobre a estratigrafia do pré-Cambriano na região de São Paulo, São Paulo, USP, Bol. IG (7): 107-112.

HASUI, Y.; HARALY, N.L.E.; MIOTO, J.A.; SAAD, A.R.; CAMPANHA, V.A.; HAMZA, V.M.; GALLI, V.A.; FRANGIPANI, A.; PULEGHINI FILHO, P. 1989. Compartimentação estrutural $e$ evolução tectônica do Estado de São Paulo. IPT/PRÓ-MINÉRIO, 2v., 288p., il (Rel. IPT N $\left.{ }^{\circ} 27.394\right)$.

; RODRIGUES, E. de P.; OLIVEI-

RA, M.C.B.D.; ENS, H.H.; MORALES, N.; ZANARDO, A.; QUADE, H.; NYK, R.; KÜLLER, M.L.; FRASCÁ. M.H.B. de O. 1988. Deformação por cisalhamento dúctil: modelo de transformações em rochas pré-cambrianas antigas do leste de São Paulo - Fase I. São Paulo, IPT/PRÓMINÉRIO, 2v. (IPT, Rel. 25.908)

HENNIES, W.T.; HASUI, Y.; PENALVA, F. 1967. O falhamento transcorrente de Taxaquara. In: CONG. BRAS. GEOL., 21, Curitiba, 1967. Anais..., Curitiba, SBG, p. 159-168.

INSTITUTO GEOGRÁFICO E GEOLÓGICO

(IGG) 1947. Carta geológica de São Paulo (Brasil), escala 1:1.000.000. São Paulo, Inst. Geogr. Geol.

JANASI, V. de A. \& UBRICH, H.H.G.J. 1991. Late Proterozoic granitoid magmatism in the State of São Paulo, Southeastern Brazil. Precam. Res., , 51:351-374.

JULIANI, C. 1992. O embasamento pré-cambriano da Bacia de São Paulo. IN: SEM. PROBL. GEOL. GEOTÉC. NA REG. METROP. S. PAULO, São Paulo, 1992. Atas..., São Paulo, ABAS-ABGESBG/NSP, p. 3-20.

1993. Geologia, petrogênese e aspectos metalogenéticos dos grupos Serra do Itaberaba e São Roque na região das serras do Itaberaba e da Pedra Branca, NE da cidade de São Paulo. (Tese de Dout. apres. ao IGUSP), 2 vol., 803 p., 5 mapas.

\& BELJAVSKIS, P. 1983. Geologia e evolução geológico-estrutural preliminar do Grupo São Roque na região da Serra de Itaberaba(SP): In: SIMP. REG. DE GEOL., 4, São Paulo, 1983. Atas..., São Paulo, SBG-NSP, p. 113-126.

; BELJAVSKIS, P.; SCHORS-

CHER, H.D. 1986. Petrogênese do vulcanismo e aspectos metalogenéticos associados: Grupo Serra do Itaberaba na região de São Roque - SP. In: CONG. BRAS. GEOL., 34, Goiânia, 1986. Anais..., Goiânia, SBG, v.2, p. 730-743.

JULIANI, C.; RICCOMINI, C.; BARROS, E.J.; BATISTUCCI. N.L.N. 1990. Proterozoic Storm-dominated sedimentation in the Pico de Itapeva Formation (São Paulo State, Brazil). An. Acad. Bras. 
Ciên., 62(1): 105.

KNECHT, T. 1950. Resumo sobre a constituição geológica do município de Franco da Rocha, São Paulo: In: KNECHT, T. (1950d) - Ocorrências Minerais do Estado de São Paulo. Inst. Geog. Geol., v. 1, p. 83.

LEFEVRE, V.; BARBOSA, AF.; WOHLERS, A.; ALMEIDA, F.F.M. de.; MELCHER, G.C.; FELICÍSSIMO JR., J.; GUIMARÃES, J.E.P.; SETZER, J.; PAOLIELLO, P.C.; FREITAS, R.O. de; MEZZALIRA, S.; PETRI, S.; KNECHT, T. 1963. Mapa Geológico do Estado de São Paulo (Brasil), Escala 1:1.000.000. Inst. Geogr. Geol.

MACHADO, R. \& FRAGOSO CÉSAR, A.R.S. 1992. Nota preliminar sobre a estruturação do Grupo Açungui no Vale do Ribeira e a norte da cidade de São Paulo. In: CONG. BRAS. GEOL., 37, São Paulo, 1992. Bol. Res. Exp...., SBG, São Paulo, v.2, p. 167.

MARINI, O.J.; TREIN, E.; FUCK, R.A. 1967. O Grupo Açungui no Estado do Paraná. In: BIGARELLA, J.J.; SALAMUNI, R.; PINTO, V.M. (Ed.) - Geologia do préDevoniano e intrusivas subseqüentes da porção oriental do Estado do Paraná. Bol. Paran. Geoc. (23 a 25): 43-103.

MORAES, L.J. de 1944a. A Serra do Japi, Estado de São Paulo. São Paulo, USP. Bol. Fac. Fil., Ciênc. e Letr. (45): 34-40. (Geol., 1).

1944b. Itacolomito em São Paulo. São Paulo, USP, Bol. Fac. Fil, Ciênc. e Letr.(45): 81-86. (Geol., 1).

$1944 c$. Níquel e cobalto nos arredores da cidade de São Paulo, São Paulo, USP, Bol. Fac. Fil., Ciênc. e Letr., (45):22-28. (Geol., 1)

MORAES REGO, L.F. de 1930. A geologia do petróleo no Estado de São Paulo. Bol. Serv. Geol. Min., (46): 1-70.

1933. Contribuição ao estudo das formações pré-devoneanas de S. Paulo. Bol. do Inst. Astron. Geogr., 43p.

MORALES, N.; OLIVEIRA, M.A.F. de; SIMÕES, L.S.A. 1985. As estruturas dobradas na região de Atibaia - SP. In: SIMP. REG. DE GEOL., 5, São Paulo, 1985. Atas..., São Paulo, SBG-NSP, v.1, p. $159-168$.

OLIVEIRA, E.P. de 1916. Geologia do Estado do Paraná. Bol. do Min. da Agric. 5(1): 6-143.

1925. Analyses de calcareos. Bol. do Serv. Geol. Min. (10): 1-45.
OLIVEIRA, F. de P. 1888. Esboço geológico da região comprehendida entre os rios Sorocaba e Tietê. In: DERBY, O.A. (1888) - Relatório 1887. Comm. Geogr. Geol. da Prov. S. Paulo, p. 25-28.

1889. Reconhecimento geológico do Valle do Paranapanema. Bol. da Comm. Geogr. Geol. Prov. S. Paulo (2): 1-31.

OLIVEIRA, M.A.F. de; MORALES, N.; CAMPOS, E.G. 1985. Geologia da Quadrícula de Atibaia - Relatório Final. IGCE-UNESP/PRÓ-MINÉRIO, 117 p.

; CARVALHO, S.G. de; MORALES, N.; CHOUDHURI, A.; ANGELI, N.; GODOY, A.M.; RUEDA, J.R.J. 1983. Geologia da porção paulista das quadrículas de Camanducaia e Monteiro Lobato. In: JORN. SOBRE A CARTA GEOL. DO EST. DE S. PAULO EM 1:50.000, 1, São Paulo, 1983. Atas..., São Paulo, SICCT/PRÓ-MINÉRIO, p. 81-107.

; BATISTA, J.J.; MORALES, N. 1987. Caracterização geoquímica de rochas anfibolíticas do Grupo Itapira nas folhas de Atibaia e Jundiaí (SP). In: SIMP. REG. DE GEOL., 6, Rio Claro, 1987. Atas..., Rio Claro, SBG, v. 1, p. 23-32.

HACKSPACHER, P.C.; GODOY, A.M. 1992a. Geologia da Folha Japi, SP em 1:25.000. In: CONG. BRAS. GEOL., 37, São Paulo, 1992. Bol. de Res. Exp...., SBG, São Paulo, v. 2, p. 129-130.

; GODOY, A.M.; ZANARDO, A.; ARTUR, A.C.; HACKSPACHER, P.C. 1992b. Geologia da Folha São Roque SP. In: CONG. BRAS. GEOL., 37, São Paulo, 1992. Bol. de Res. Exp..., SBG, São Paulo, v. 2, p. 126-127.

PETRI, S.; COIMBRA, A.M.; AMARAL, G.; OJEDA Y OJEDA, H.; FÚLFARO, V.J.; PONÇANO, W.L. 1986a, Código Brasileiro de Nomenclatura Estratigráfica (pela Comissão Especial de Nomenclatura Estratigráfica da SBG). Rev. Bras. Geoc., 16(4): 372-376.

PETRI, S.; COIMBRA, A.M.; AMARAL, G.; PONÇANO, W.L. 1986b. Guia de Nomenclatura Estratigráfica (pela Comissão Especial de Nomenclatura Estratigráfica da SBG). Rev. Bras. Geoc.; 16(4): 376-415.

PIRES, F.A.; FERNANDES, A. J.; TEIXEIRA, A.L.; BOGGIANI, P.C.; MASSOLI, M.; PETRI, S. 1990. Mapa geológico da Folha Salto de Pirapora - SP (SF-23-YC-IV-2), na escala 1:50.000. In: CONG. 
BRAS. GEOL., 36, Natal, 1990. Bol. de Res...., Natal, SBG, p. 352.

SADOWSKI, G.R. \& TASSINARI, C.C.G. 1988. The São Roque volcano-sedimentary sequence of proterozoic age. In: INTERN. GOND. SYMP., 7, São Paulo, Brazil. Excursions. (no prelo).

SANTORO, E. 1984. Geologia da Folha Cabreúva, SP. São Paulo, 114p. (Diss. Mest. apres. ao IGUSP).

; ENS, H.H.; NAGATA, N. 1991. Geologia das folhas Jacareí, Tremembé, Taubaté e Pindamonhangaba - SP. Parte I: Embasamento setentrional da Bacia de Taubaté. In: SIMP. GEOL. SUD., 2, São Paulo, 1991. Bol. de Res..., São Paulo, SBG-NSP/NRJ, p. 46.

\section{; CARNEIRO, C.D.R.; OLIVEI-}

RA, M.C.B. de; HACHIRO, J. 1988. Estrutura geológica da região de Cajamar-Jordanésia, SP. Rev. Bras. Geoc., 18(3): 353-361.

SILVA, L.C. da; THEODOROVICZ, A.; SANTARÉM, P.C.; YAMATO, A.A.; VASCONCELOS, C.S.; MORAES, S.M.; PERROTA, M.M. 1991. Análise microestrutural nos metapelitos do Complexo Embu. In: SIMP. GEOL. SUD., 2, São Paulo, 1991. Bol. de Res..., São Paulo, SBG-NSP/NRJ, p. 45.

SIMÕES, L.S.A.; VALERIANO, C. de M.; MORALES, N. 1986. Aspectos estruturais observados nas adjacências da Falha de Jundiuvira e o problema da relação dos Grupos Amparo e São Roque. In: CONG. BRAS. GEOL., 34, Goiânia, 1986. Bol. de Res..., Goiânia, SBG, p. 120-121.

TASSINARI, C.C.G. 1988. As idades das rochas e dos eventos metamórficos da porção sudeste do Estado de São Paulo e sua evolução crustal. (Tese de Dout. Apres. ao IGUSP), São Paulo, 236 p.

TASSINARI, C.C.G.; KAWASHITA, K.; KIKUCHI, R.K.P. de 1985. Estudo geo- cronológico nos metaconglomerados do Grupo São Roque, no Estado de São Paulo. In: SIMP. REG. DE GEOL., 5, São Paulo, 1985. Atas..., São Paulo, SBG-NSP, v. 1, p. 201-208.

\section{; KAWASHITA, K.; VAN}

SCHUMUS, R.; TAYLOR, P.N. 1988. As idades das rochas e dos eventos metamórficos da região sudeste do Estado de São Paulo. In: CONG. BRAS. GEOL., 35, Belém, 1988. Anais..., Belém, SBG, v. 6 , p. $2840-2848$.

THEODOROVICZ, A.; YAMATO, A.A.; VASCONCELOS, C.S.; SANTARÉM, P.C.; SILVA, L.C. da; SILVA, V.A. da 1991. Características lito-estruturais do Cinturão de Cisalhamento Transcorrente de São Paulo - Região leste da Grande São Paulo. In: SIMP. GEOL. SUD., 2, São Paulo, 1991. Bol. de Res...., São Paulo, SBG-NSP/NRJ, p. 44-45.

VANDOROS, P. \& FRANCO, R.R. 1966. Determinações de idades de granitos da região de Mogi das Cruzes, São Paulo, pelos métodos potássio-argônio e rubídio-estrôncio. An. Acad. Bras. Ciênc. 38(2): 289-292.

VAN SCHUMUS, W.R.; TASSINARI, C.C.G.; CORDANI, U.G. 1986. Estudo geocronológico da parte inferior do Grupo São Roque. In: CONG. BRAS. GEOL., 34, Goiânia, 1986. Anais..., Goiânia, SBG, v.3, p. 1399-1406.

VIEIRA, S.R.S.S. 1989. Estudo lito-estrutural da região de Embu-Guaçu - Parelheiros, São Paulo. São Paulo, 122p. (Diss. Mest. apres. ao IGUSP).

WERNICK, E. \& GALEMBECK, T.M.B. 1986. Caracterização do plutonismo granitóide do Ciclo Brasiliano no Estado de São Paulo através do método da tipologia do zircão. In: CONG. BRAS. GEOL., 34, Goiânia, 1986. Anais..., Goiânia, SBG, v. 3, p. 1369-1382.

Endereço dos autores:

Caetano Juliani - Departamento de Mineralogia e Petrologia - Instituto de Geociências - Universidade de São Paulo - Caixa Postal 20899 - 01498-970 - São Paulo, SP - Brasil. (E-Mail:cjuliani@usp.br.)

Paulo Beljavskis - Instituto de Pesquisas Tecnológicas do Estado de São Paulo S/A - IPT - Cidade Universitária Armando de Salles Oliveira - Butantã - Caixa Postal 7141 - 05508-901 - São Paulo, SP - Brasil. 